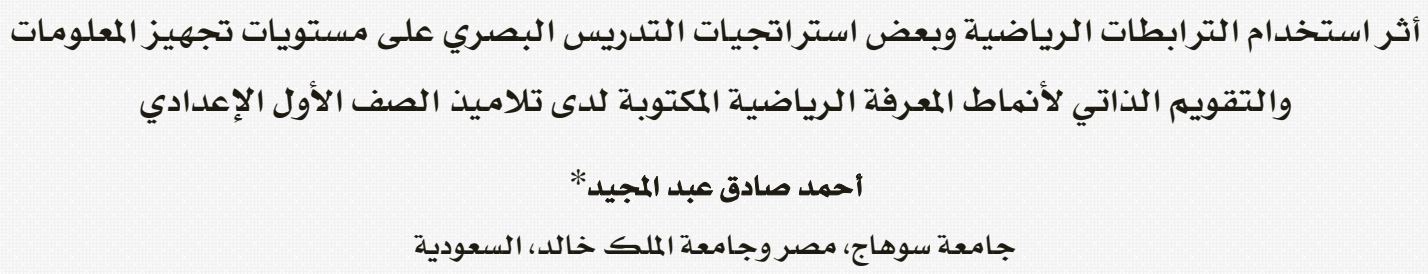

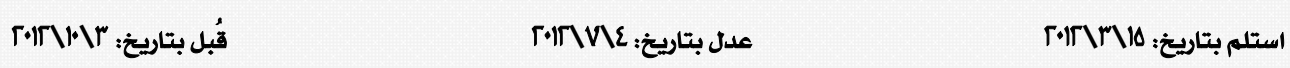

هدف البحث الحالي إلى تعرف أثر استخدام استراتيجية الترابطات الرياضية وبعض استراتيجيات التدريس البصري على مستويات تجهيز المعلومات والتقويم الذاتي لأنهاط المعرفة الرياضية المكتوبة، وذلك عند تلاميذ الصف الأول الإعدادي. ولتحقيق هذا الهدف تم اختيار ثلاث مجموعات: اثنتين منها تجريبية، والثالثة ضابطة. تم تدريس محتوى وحدة "الجبر" للمجموعة التجريبية الأولى وعددها هو تلميذاً وفقاً لاستراتيجية الترابطات الرياضية، والمجموعة الثانية وعددها رب تلميذاً درست المحتوى نفسه وفقاً

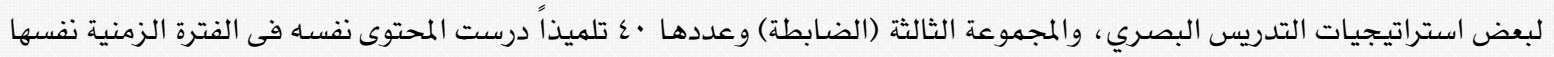
وفقاً للطريقة المعتادة فى التدريس. وقد تم إعداد وحدة " الجبر" باستخدام استراتيجية الترابطات الرياضية، وإعداد الوحدة نفسها باستخدام بعض استراتيجيات التدريس البصري، كمها تم إعداد دليل للمعلم قائم على استراتيجية الترابطات الرياضية، ودليل أخر

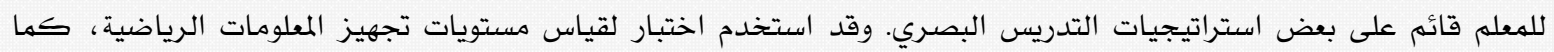
استخدم مقياس لتقويم أنماط المعرفة الرياضية المكتوبة وذلك لدى المجموعات الثلاثة. وقد أشارت النتائج إلى أن استخدام استراتيجية الترابطات الرياضية، وبعض استراتيجيات التدريس البصري فى تدريس وحدة " الجبر" قد أسهما فى رفع مستويات تجهيز

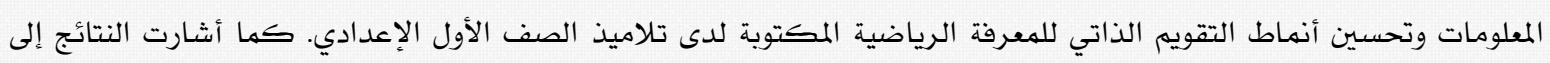
تساوى أثر استخدام استراتيجية الترابطات الرياضية، وبعض استراتيجيات التدريس البصري على مستويات تجهيز المعلومات،

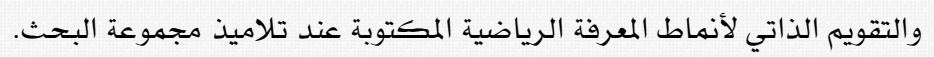
الكلمات المفتاحية: الترابطات الرياضية، والتدريس البصري، تجهيز المعلومات، أنماط المعرفة.

\title{
The Effect of Using M athematical Correlations and Some V isual Teaching Strategies on the Levels of Information Processing and Self Evaluation of the Written Mathematical Knowledge Patterns of the First year Preparatory Students
}

\author{
A hmed S. Abdelmajead* \\ Sohag University, Egypt \& King Khaled University, Kingdom of Saudi A rabia
}

This research aimed at identifying the effect of using mathematical correlations and some visual teaching strategies on the levels of information processing and self-evaluation of the written mathematical knowledge patterns of the first year preparatory students. To achieve this aim, three groups were selected: two of them were experimental, and the third was a control one. An Algebra unit was taught to the experimental group (39 students) according to the mathematical correlations; and the second experimental group (38 students) studied the same content, according to some visual teaching strategies, and the third group (the control group) (40 students) studied the same content in the same time period according to the usual method used in teaching. The Algebra unit was prepared using the mathematical correlations strategy and some visual teaching strategies. A teacher's manual based on the aformentioned strategies was al so prepared. A test for measuring mathematical information processing and a scale for evaluating the written mathematical knowledge patterns was administered to the three groups. The results showed that using mathematical correlations and some visual teaching strategies in teaching the Algebra unit contributed to raising the level of information processing as well as the written mathematical knowledge patterns of the first preparatory students. The results also indicated equal use of the mathematical correlations and some visual teaching strategies on the level of information processing and self evaluation of the written mathematical knowledge patterns of the first year preparatory students.

Keywords: mathematical correlations - visual teaching - information processing - knowledge patterns.

*ahmedsadek@yahoo.com 


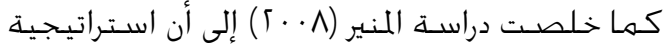

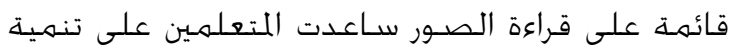

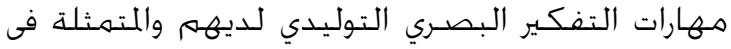

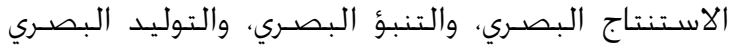

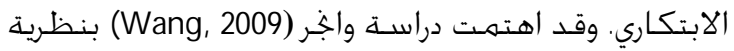

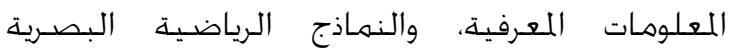

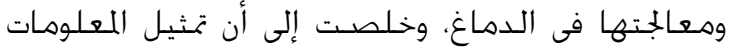

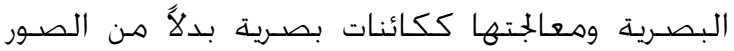

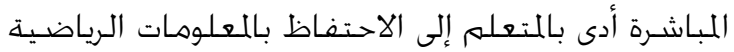

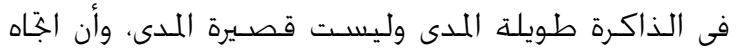

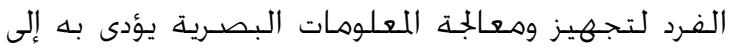

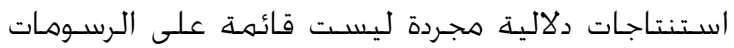

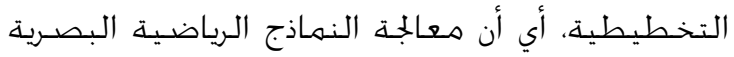

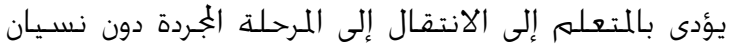

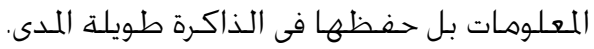

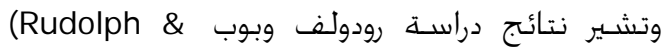
Popp, 2007)

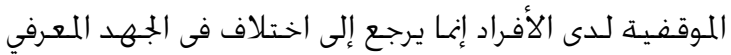

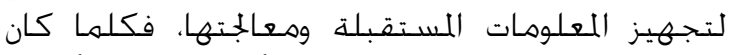

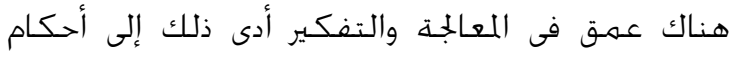

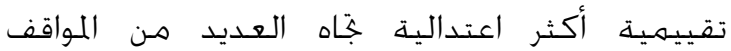
الاجتـماعية.

ويهتهم هستـوى جَهيز المعلوهات بالطريقـة التى يتبعها

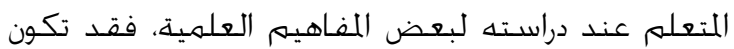

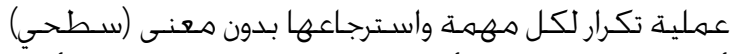
أو إدراك معناها وإيكاد أوجهـ التشابه بينها وبين مهمهـ أخري

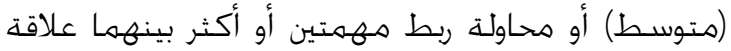

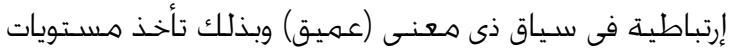

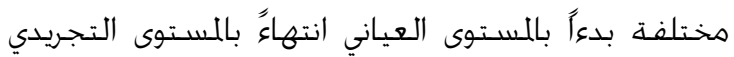

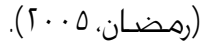

والانتقال بتدريس الرياضيات إلى ثقافة بناء وجّهيز

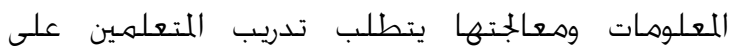

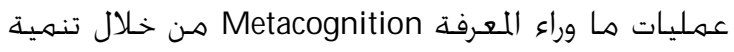

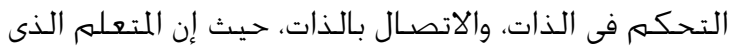

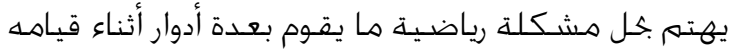

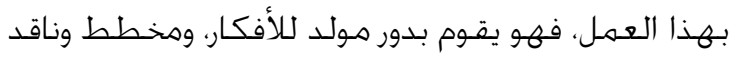

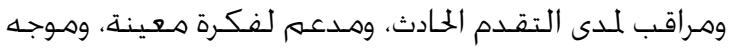

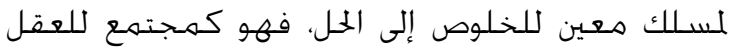
يضع أماهـ منظورات متعددة ويقيم Society of mind

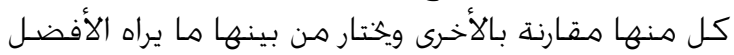

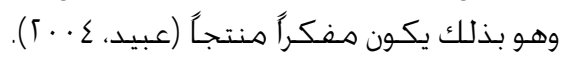

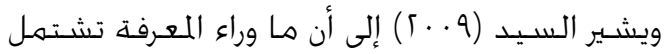

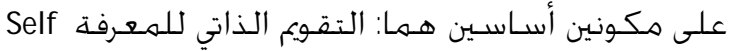
appraisal of cognition المعرفة Knowledge of cognition أما المكون الثانى

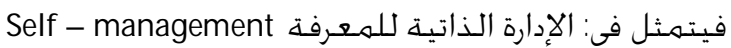

تتميز الرياضيات بأنها لغة ترابط فهى تترابط هع

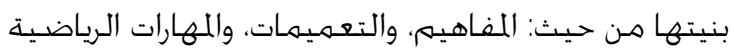

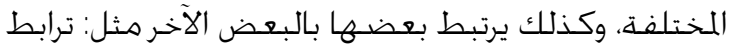

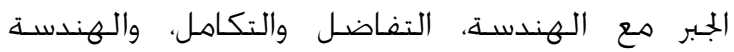

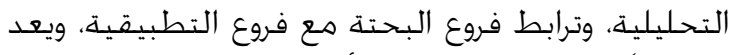

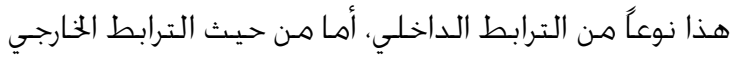

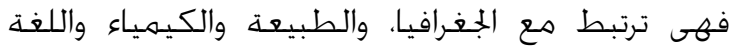
العربية وغيرها هن فروع العلم المختلفة.

وحتـى يكون للرياضـيات معنى يجـبـ أن يتهم تعليمها

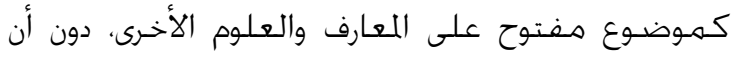

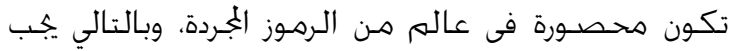

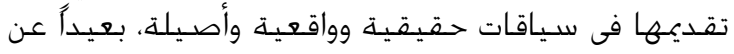

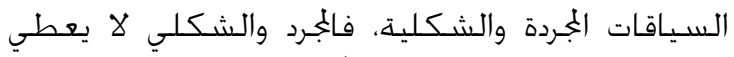

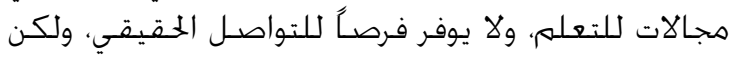

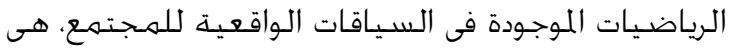

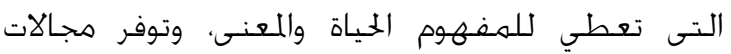
متعددة لبناء المعانى (جاير، كشـك، V ل . ؟).

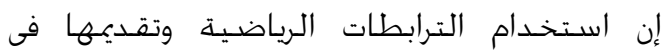

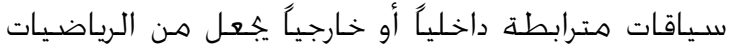

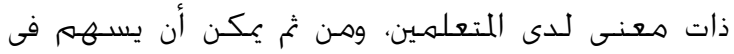

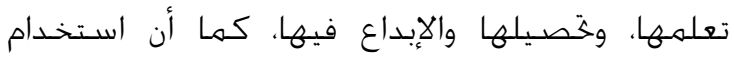

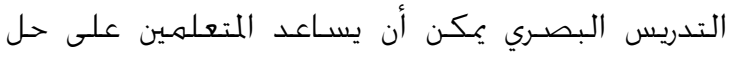

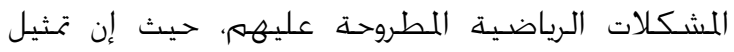

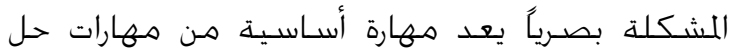

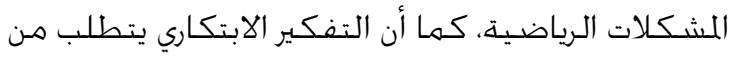

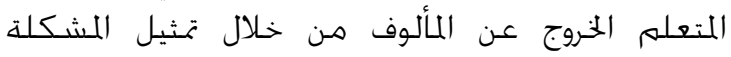
الرياضـية بـــور مختلفة.

ويرى المقوشى (ا . . ؟) أن الإنسـان يتعرض لكمى هائل

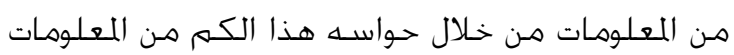

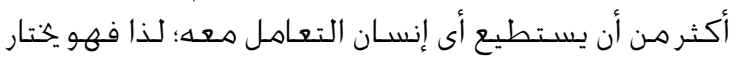

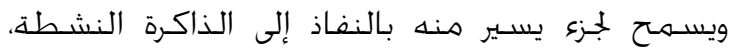

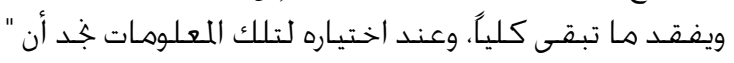

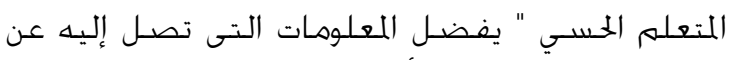

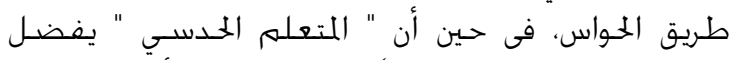

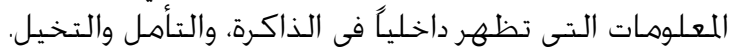

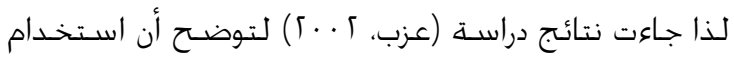

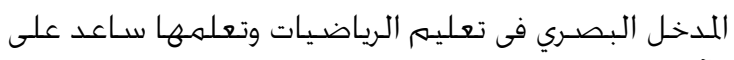
الآتي:

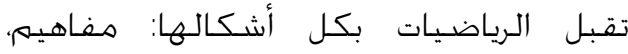

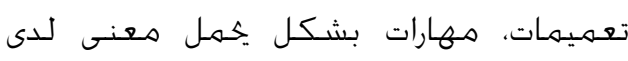

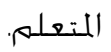

إعطاء المتعله دوراً كبيرًا في عملية فهم الرياضـيات بكل أشـكالهـا. جعل تعليم الرياضـيات باقى الأثر. 


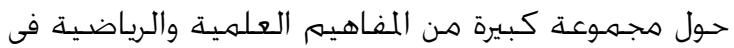

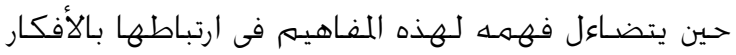

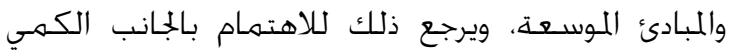

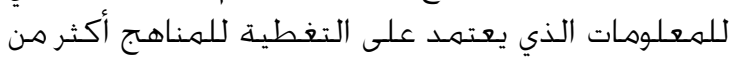

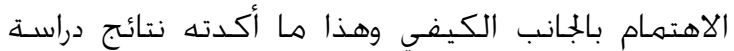

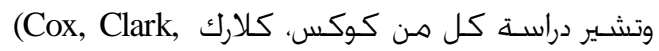
(1998)

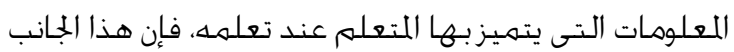
له يلق الاهتمام الكافي من قبل القائمين بالتدريس، حيث ليثان

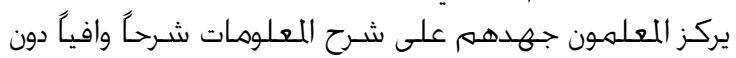

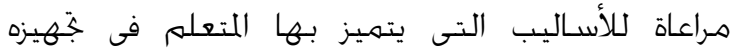

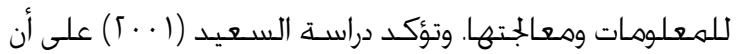

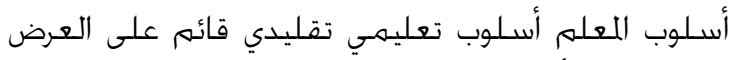

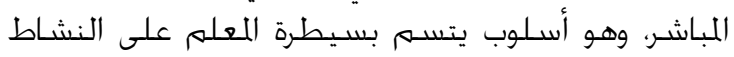

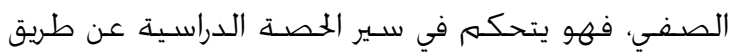

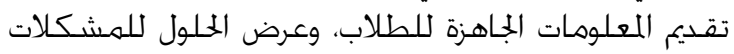

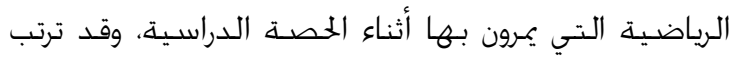

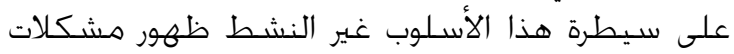
تدريسية كثيرة أبرزها: التركيز على التدريب الآلي، والحفظ.

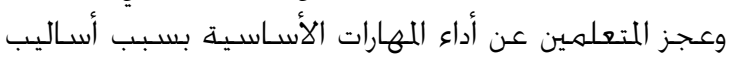

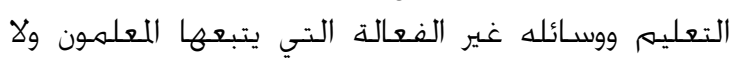

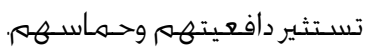

فكثير من المعلمين يلجأون إلى تدريس رياضيات

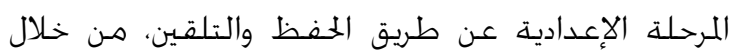

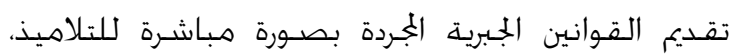

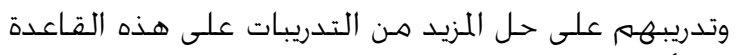

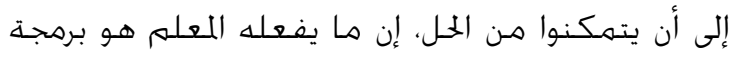

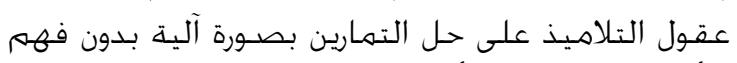

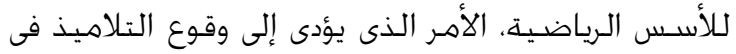

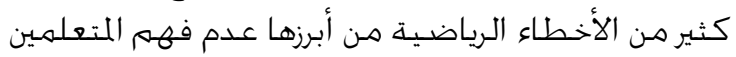

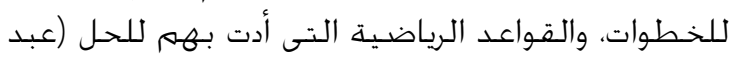

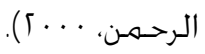

وقد خلصت دراستة (رمضان، ه · · ) إلى أن واقع التدريس

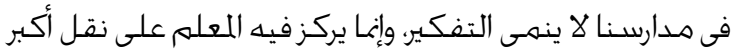

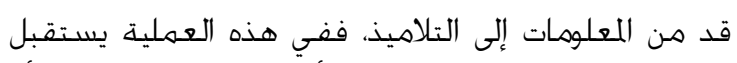

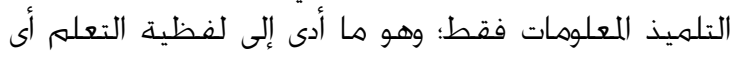
حفظ وترديد محتوى المادة الدراسية، وقد اتضح ذلك إلك من خلال تطبيق مقياس مستويات جزهيز المعلومات (السطحي.

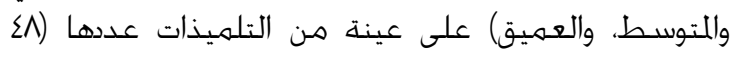

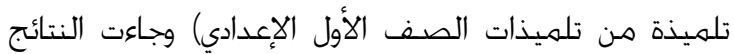

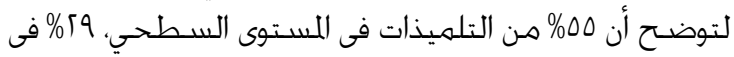
المستوى المتوسط، 1 \% في المستوى العميق، أى أن نسبة كبئ كبيرة

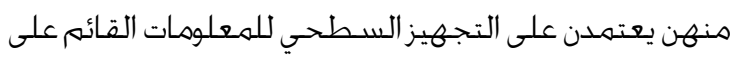
الحفظ والترديد دون معنى على التهنيز
وقد يطلق عليها تنظيم المعرفة of cognition Regulation of cognition

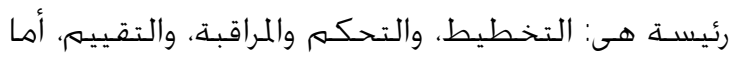

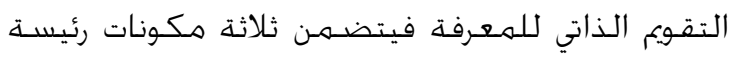

أ - المعرفة التقريرية Declarative knowledge وتمثل معرفتنا عن أنفسينا كمتعلمين ومعرين ومعرفتنا عن العواهل التى تؤثر في أدائنا التعليمي.

ب - العرفة الإجرائية Procedural knowledge وتمثل معرفتنا عن الطرق، والاستراتيجيات، والإجراءات المختلفة المستخدمة فئنا ألمائنا. جـ- الععرفة الشـرطية Conditional knowledge وتشير إلى معرفة لماذا ومتى نستخدم هذه الاستراتيجيات.

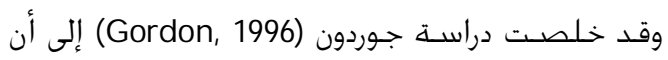

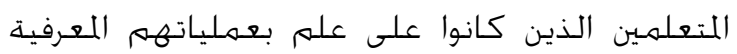

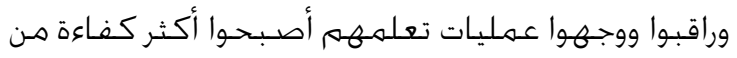

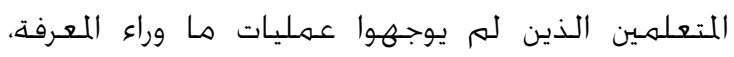

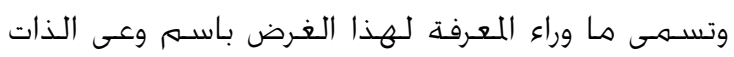
عن الفرد بعملياته المعرفية.

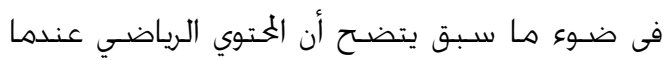

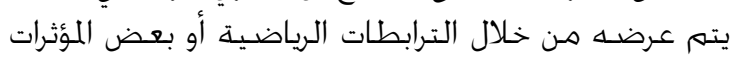

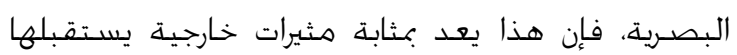

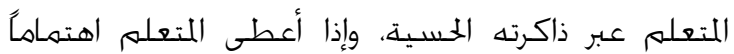

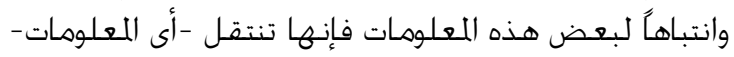

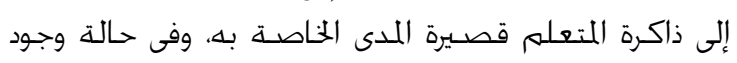

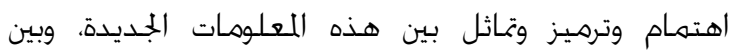

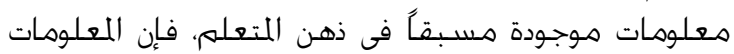

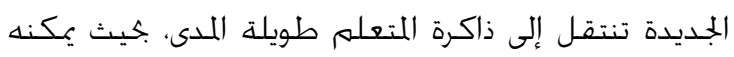

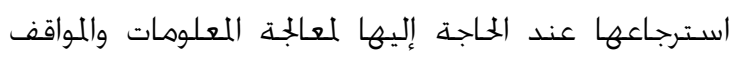
الرياضية المختلفة.

بالإضافة إلى ذلك فإن تعرض المتعلم للمثيرات

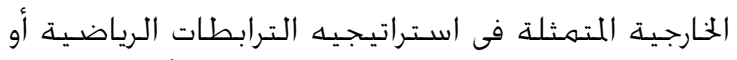

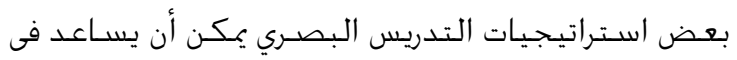

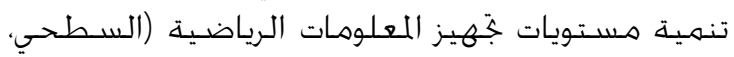

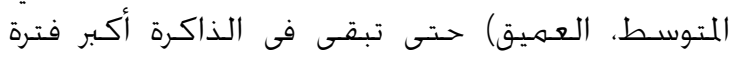

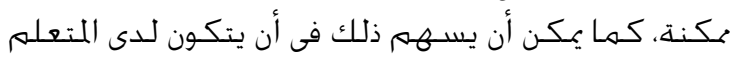

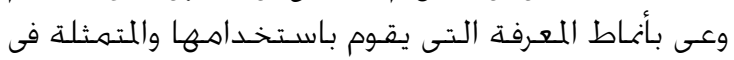

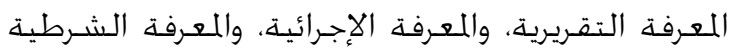
وذلك في محتوى رياضيات الصفـ الأول الإعدادي.

مشكلة الدر اسة:

يركز الوضع الراهن للتدريس على مفهوم التغطية،

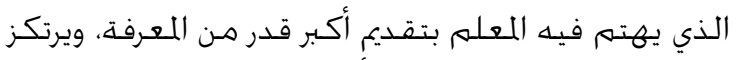

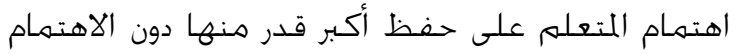

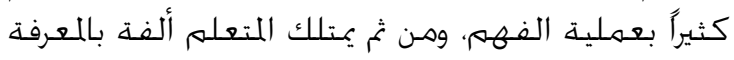


استراتيجيات تفتقر إلى النضج المعرفي في حل المسائل

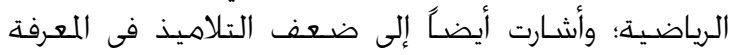

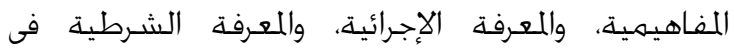

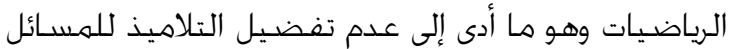

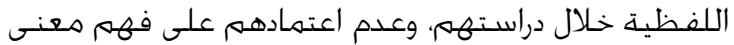
المسألة اللفظية لتفسير خطوات حلهم للمسائل أو نتائج حلهم واعتمادهم فقط على الكلمات الافتتاحية كمؤشر لحل المسائل اللفظية.

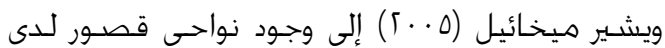

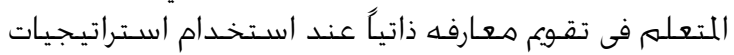

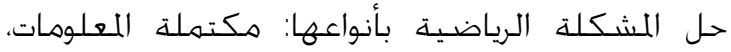

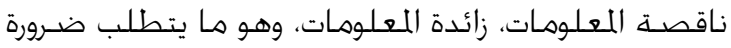

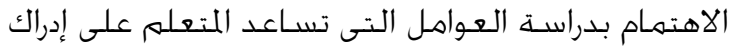

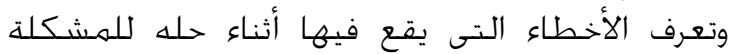

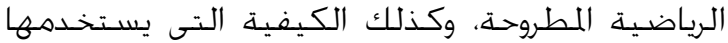

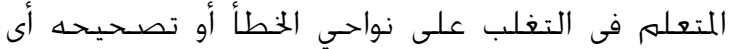

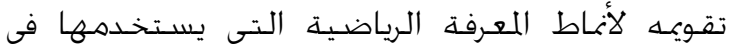

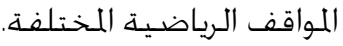

وقد خلصت دراسـة حبيب (1 · ) إلى أن تدريس الجبر

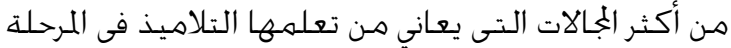

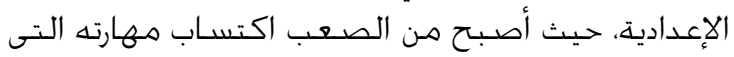

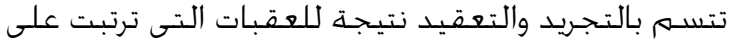

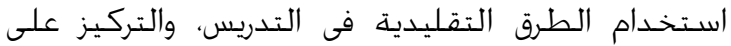

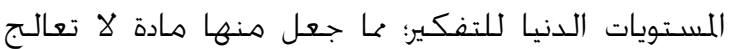

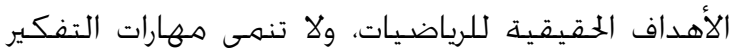

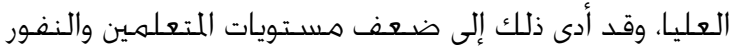

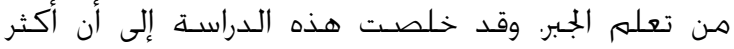

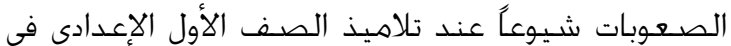

$$
\text { مقرر الجبر تتمثل فى الآتي: }
$$

$$
\text { " التميز بين الحـد الجبـبري، والمقدار الجبـري. }
$$$$
\text { ضـرب حسد جبري في مقدار جـبري. }
$$

جهع الحدود والمقادير الجببرية وطرحها.

$$
\text { توظيف قوانين الأسـس على الحدود الجبرية. }
$$

ما سبق خددت مشكلة البحث الحالي في تدني

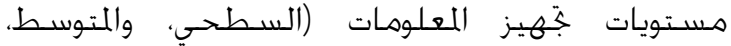

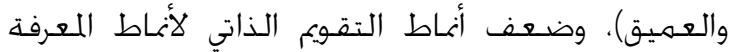

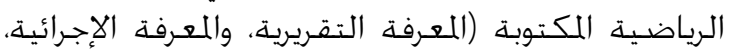

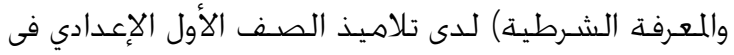

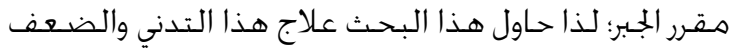

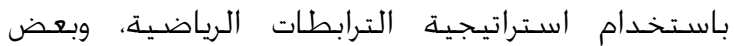
استراتيجيات التدريس البصـري.

\section{هدف الدر اسة: - مل}

هدف البحث إلى تنمية مستويات جَهيز المعلومات (السطحي، والمتوسط، والعميق) والتقويم الذاتي لأنماط التهات

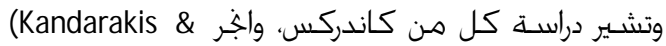
Poulos, 2008)

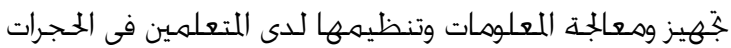

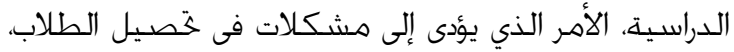

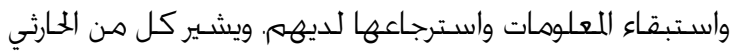

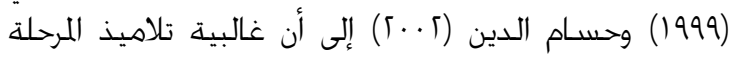

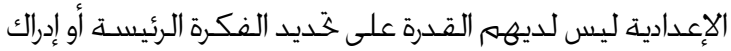

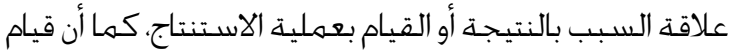

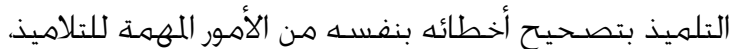

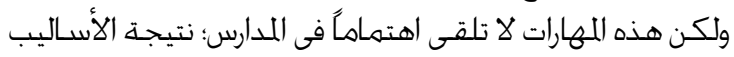

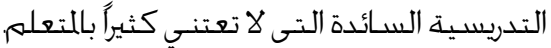

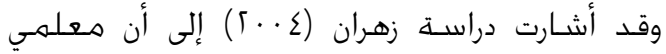

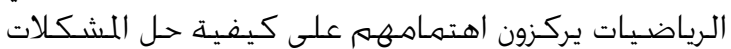

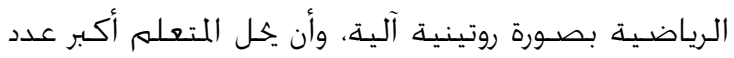

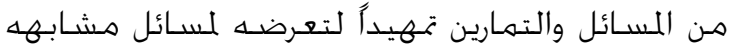

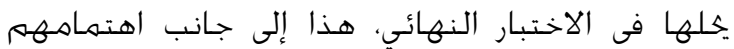

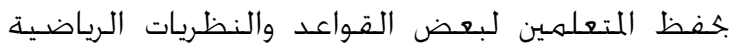

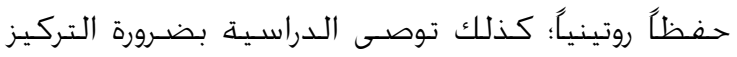

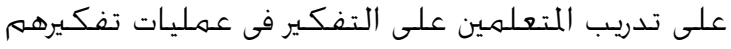

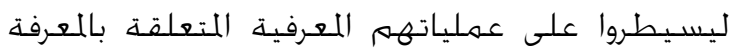

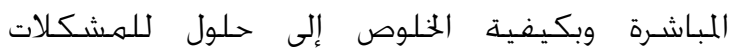

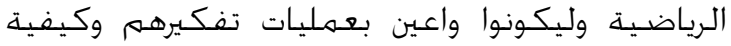
التحكم فيها وتوجيه8ها.

إن بعض المتعلمين ليس لديهم أدنى فكرة عما ينبغى

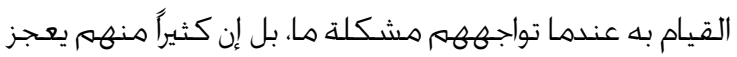

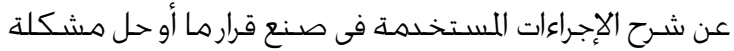

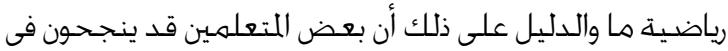

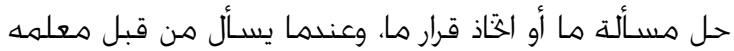

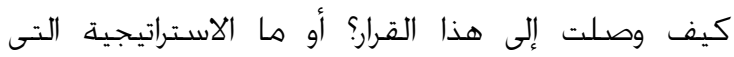

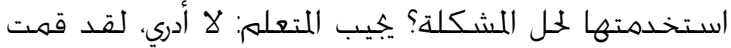

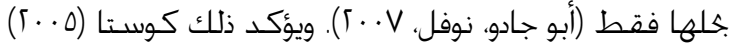

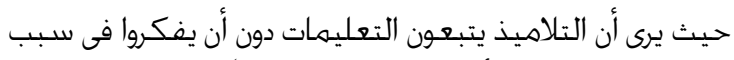

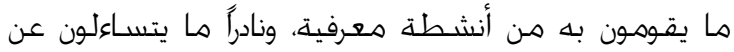

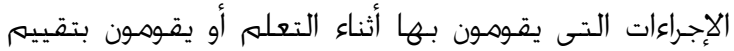

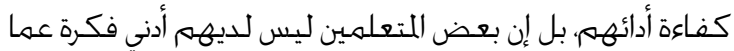
يقومون به من استراتيجيات عند حل المشكلة الرياضية التئي وقد جاءت نتائج دراسـة كل من الوهر، أبو عليا (1999)

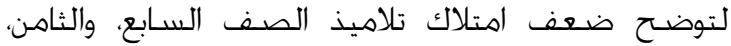
والتاسع للمعارف الثلاثة لما وراء المعرفة والمتمثلة في المتائل العرفة

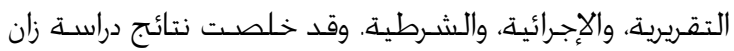
(Zan, 2000)

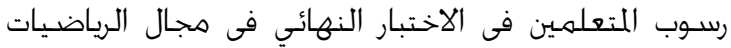

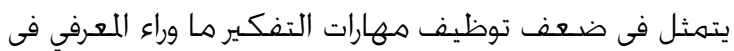

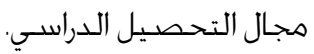

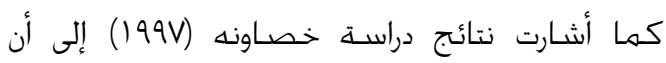

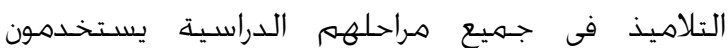


لأنماط المعرفة الرياضية المكتوبة لدى تلاميذ الصف الأول

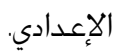

$$
\text { وقد تفرع من الفرض الرئيس الفروض الآتية: }
$$

1 ه ·. · بين متوسطي درجات الجمهموعة التجريبية

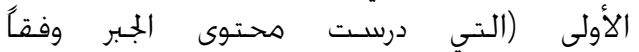
لاستراتيجية الترابطات الرياضية) والضـابطة

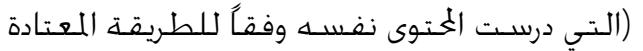

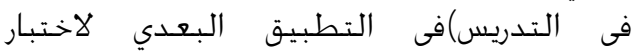
مستويات جّهيز المعلومات.

r - ل لا يوجد فرق ذو دلالة إحصائية عند مستوى دلالة

ه • , بين متوسيطي درجات المجموعة التجريبية الأولى دلى

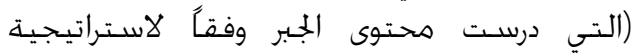
الترابطات الرياضية) والضابطة (التي درست لالتيت

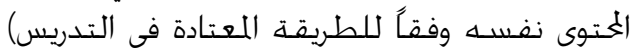

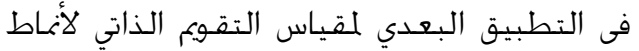
المعرفة الرياضية المكتوبة.

r - لا يوجد فرق ذو دلالة إحصائية عند مستوى دلالة

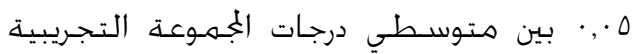

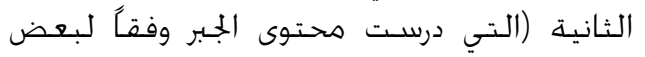

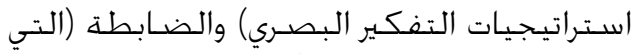

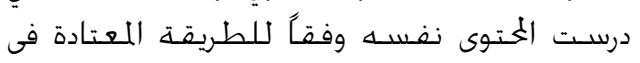
التدريس) في التطبيق البعدي لاختبار مستويات جنهيز المعلومات.

ع - لا يوجد فرق ذو دلالة إحصائية عند مستوى دلالة

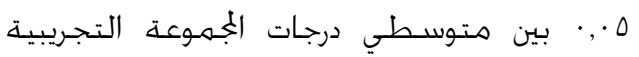

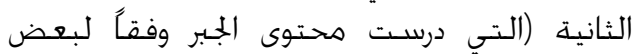

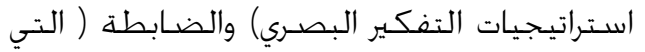

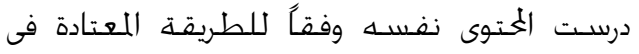
التدريس) في التطبيق البعدي للقياس التقويم الذاتي لأنماط المعرفة الرياضية المكتوبة.

ه - لا يوجد فرق ذو دلالة إحصائية عند مستوى دلالة

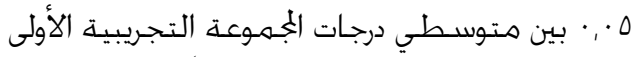

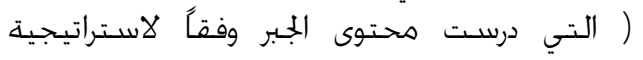
الترابطات الرياضية) والمجموعة التجريبية الثانية لإنية

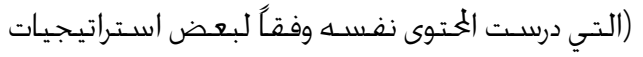
التفكير البصري) في التطبيق البعدي لاختبار مستويات جُهيز المعلومات.

ا - - لا يوجد فرق ذو دلالة إحصائية عند مستوى دلالة

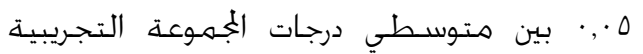
الأولى (التي درست محتوى الجببر وفقاً لاستراتيجية التجرية الترابطات الرياضية)، والجمهوعة التجريبية الثانية لالتية

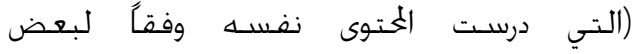
استراتيجيات التفكير البصري) في التطبيق البعدي
المعرفة الرياضية (التقريرية، والإجرائية، والشـرطية) لدى

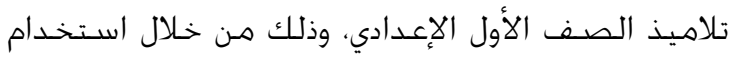

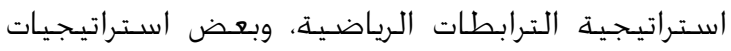

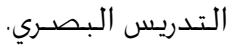

أسئلة الددراسة:"

حاول البحث الحالي إجابة السؤوال الرئيس الآتي: ما أثر استخدام استراتيجية الترابطات الرياضية.

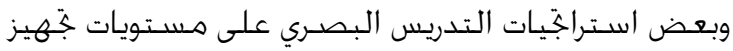

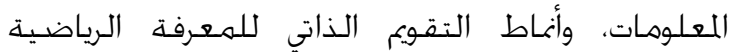
اللكتوبة لدى تلاميذ الصف الأول الإعدادي؟

وقد تفرع من هذا السؤال الأسئلة الفرعية الآتية: 1 - ـ ما أثر استـخدام استراتيجية الترابطات الرياضية

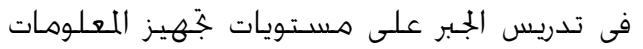
لدى تلاميذ الصف الأول الإعدادي؟

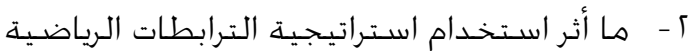

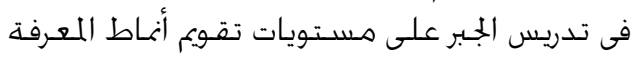

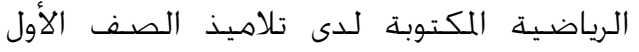

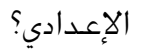

r - ما أثر استخدام بعض استراتيجيات التفكير

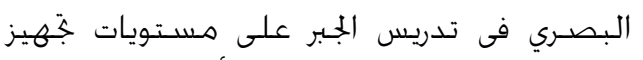
المعلومات لدى تلاميذ الصف الصبر علأول الإعدادي؟

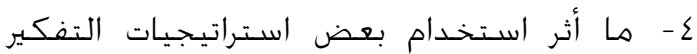

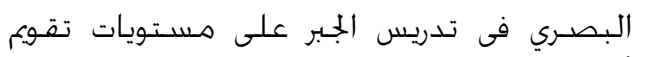
أنماط الععرفة الرياضية المكتوبة لدى لدئ تلاميذ الصف الأول الإعدادي؟ العرياص

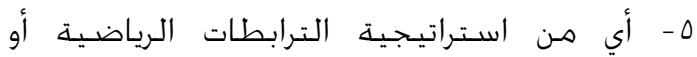

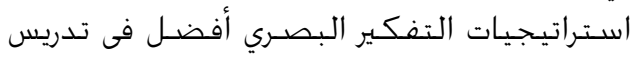

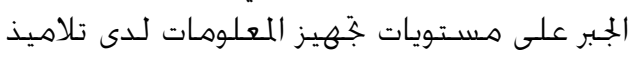
الصف الأول الإعدادي؟

1 - أي هن استراتيجية الترابطات الرياضية أو أولئية

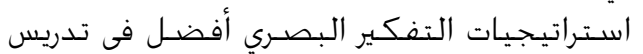

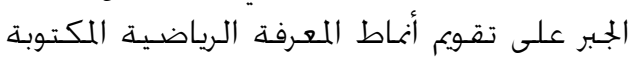
لدى تلاميذ الصف الأول الإعدادي؟ العير العياض

فروض الدراسة:

حاول البحث الحالي التحقق من صحة الفرض

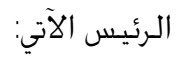

لا توجد فروق ذات دلالة إحصائية عند مستوى دلالة

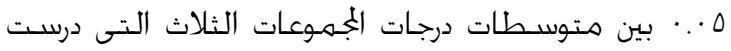

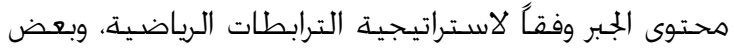

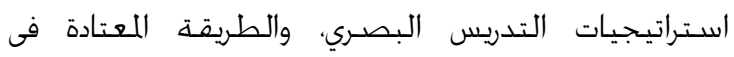
التدريس على مستويات جُهيز المعلومات، والتقويم الذاتي لطئي 
تحديد مصطلحات الدراسة:

تم خَديد مصـطلحات البحـث بصـورة إجـرائية على

$$
\text { النحـو الآتي: }
$$

$$
\text { ا. الترابطات الرياضية: }
$$

هى نسـق تكاملي قائم على التكامل بين جوانب التباه التعلم في الدرس الواحــ والمتمثل في المفـاهيم

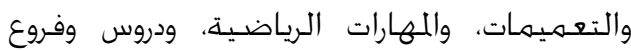
الرياضيات الأخرى، وكذلك بين مجال الرياضيات.

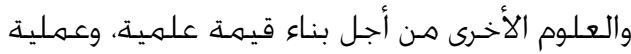

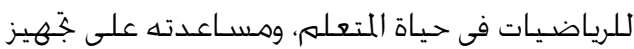

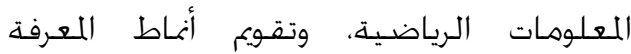
الرياضـيـة المكتوبة بصـورة فعالة.

$$
\text { ז. التدريس البصري: }
$$

هو مجموعة مـن الأنشـة التعليمية المختلفة التي

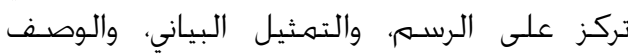

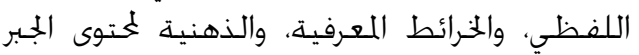

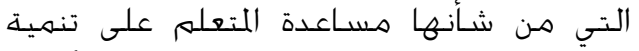

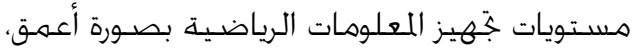
وكذلك على تقويم أنماط المعرفة الرياضية المكتوبة.

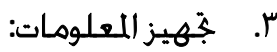

هو مجهموعة هن الإجراءات أو الطرق التى يتبعها

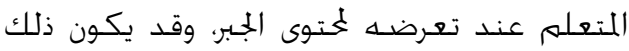

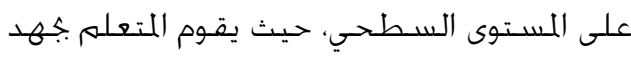

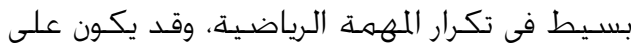

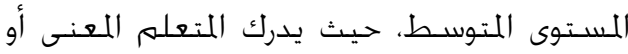

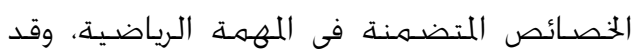

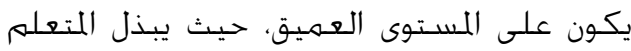

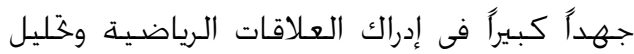
المعاني المتضـمنـة في اللهمهـة الرياضية.

ع. التقويم الذاتي لأنماط المعرفة:

هو وعى المتعلى باللهارات والمصـادر اللازمة لإجناز

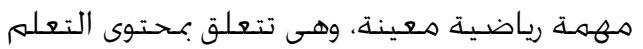

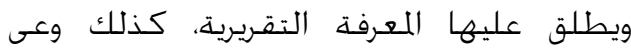

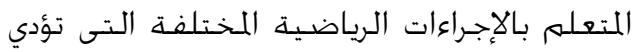

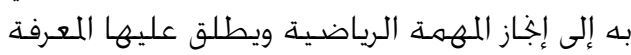

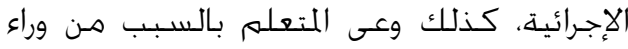

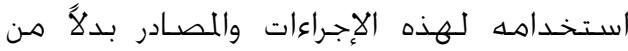

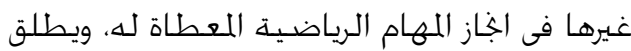

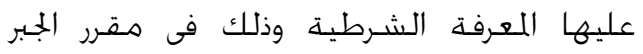
لتـلاميـذ الصـف الأول الإعـدادي.

للقياس التقويم الذاتي لأنماط المعرفة الرياضية المكتوبة.

\section{أهمية الدراسة:}

تتمثل أهـميـة البـــث الخالي في الآتي:

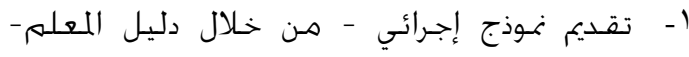
يوضسح كيفية استخـدام استراتيجية الترابطات

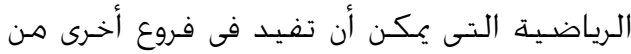
فروع الرياضيات.

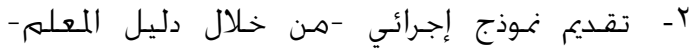

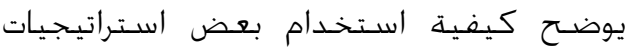

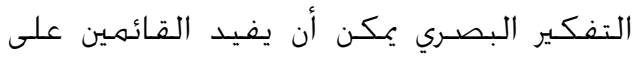

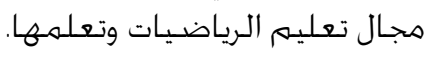

r- تقديم اختبار لقياس مستويات جَهيز المعلوهات، يمكن

أن يفيد المهتمين بمجال تعليم الرياضيات وتعلمهاريا. ع- تقديم مقياس لتقويم أنماط المعرفة الرياضية المكتوبة يمكن أن يفيد الباحثين في مجال تعليم الرياضيات وتعلمها.

0- توجيه نظر القَائمين على مجال تعليم وتعلم العات

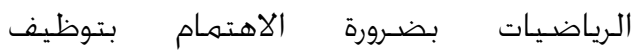

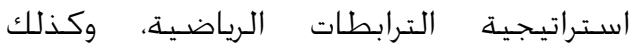

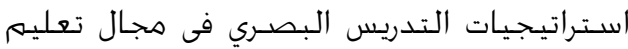
الرياضيات وتعلمها.

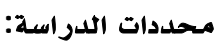

$$
\begin{aligned}
& \text { اقتصـر البـحث الخالي على العـددات الآتية: }
\end{aligned}
$$

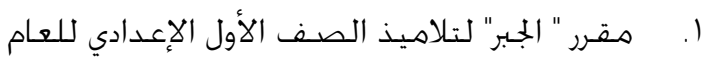

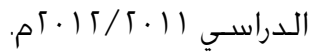

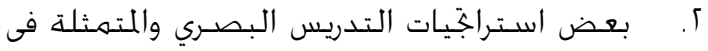

$$
\begin{aligned}
& \text { الآتي: }
\end{aligned}
$$

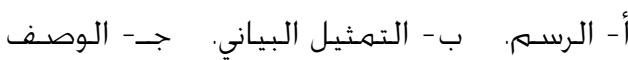

$$
\begin{aligned}
& \text { اللفظي. د - الخرائط المعرفية والذهنية. }
\end{aligned}
$$

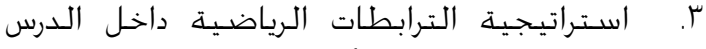

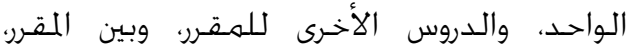

$$
\begin{aligned}
& \text { والمقررات الدراسـيـة الأخـرى. } \\
& \text { ع. قياس هسـتويات جتهيز المعلوهات على المسـتويات }
\end{aligned}
$$

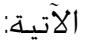

$$
\begin{aligned}
& \text { أ - السـطحي. ب - المتوسـط. جـ - العـميق. } \\
& \text { 0. قياس التقويم الذاتي لأنماط المعرفة الرياضية } \\
& \text { المكتوبة، والمتمثلة في الآتي: } \\
& \text { أ - المعرفة التقريرية ب - المعرفة الإجرائية. جـ - } \\
& \text { المعرفة الشـرطية. }
\end{aligned}
$$




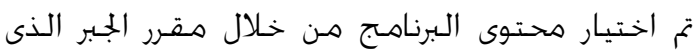

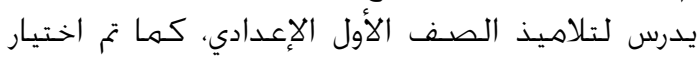

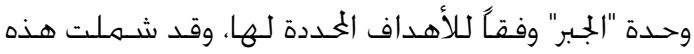
الوحدة الـروس التعليميـة الآتية:

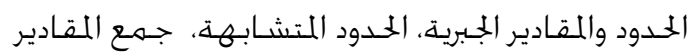

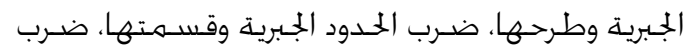

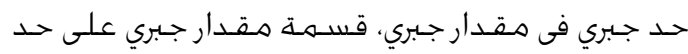

جباري. جـ - ختديد أسبلوب تـدريس البرناهـ:

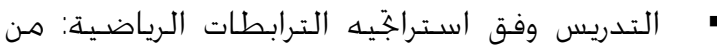

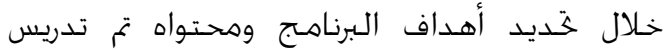

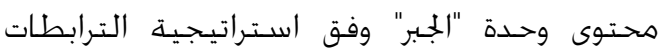

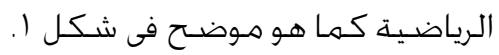

\section{الطريقة والإجراءات}

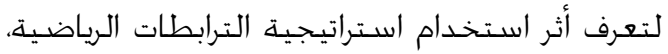
وبعض استراجيّات التدريس البصـري على مستويات جُّهيز

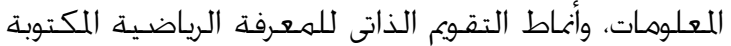

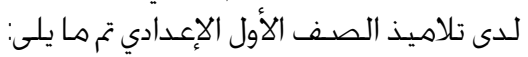

أولاً: إعداد مواد البحث:

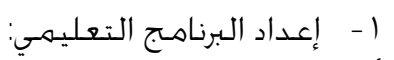

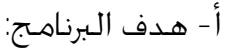

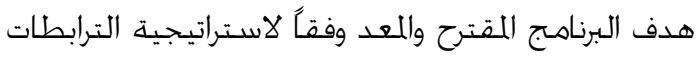

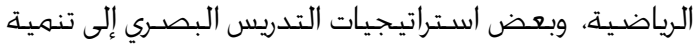

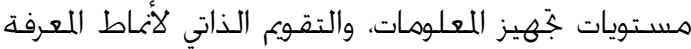
الرياضية لدى تلاميذ الصـف الأول الإعدادي. لـوني.

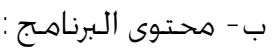

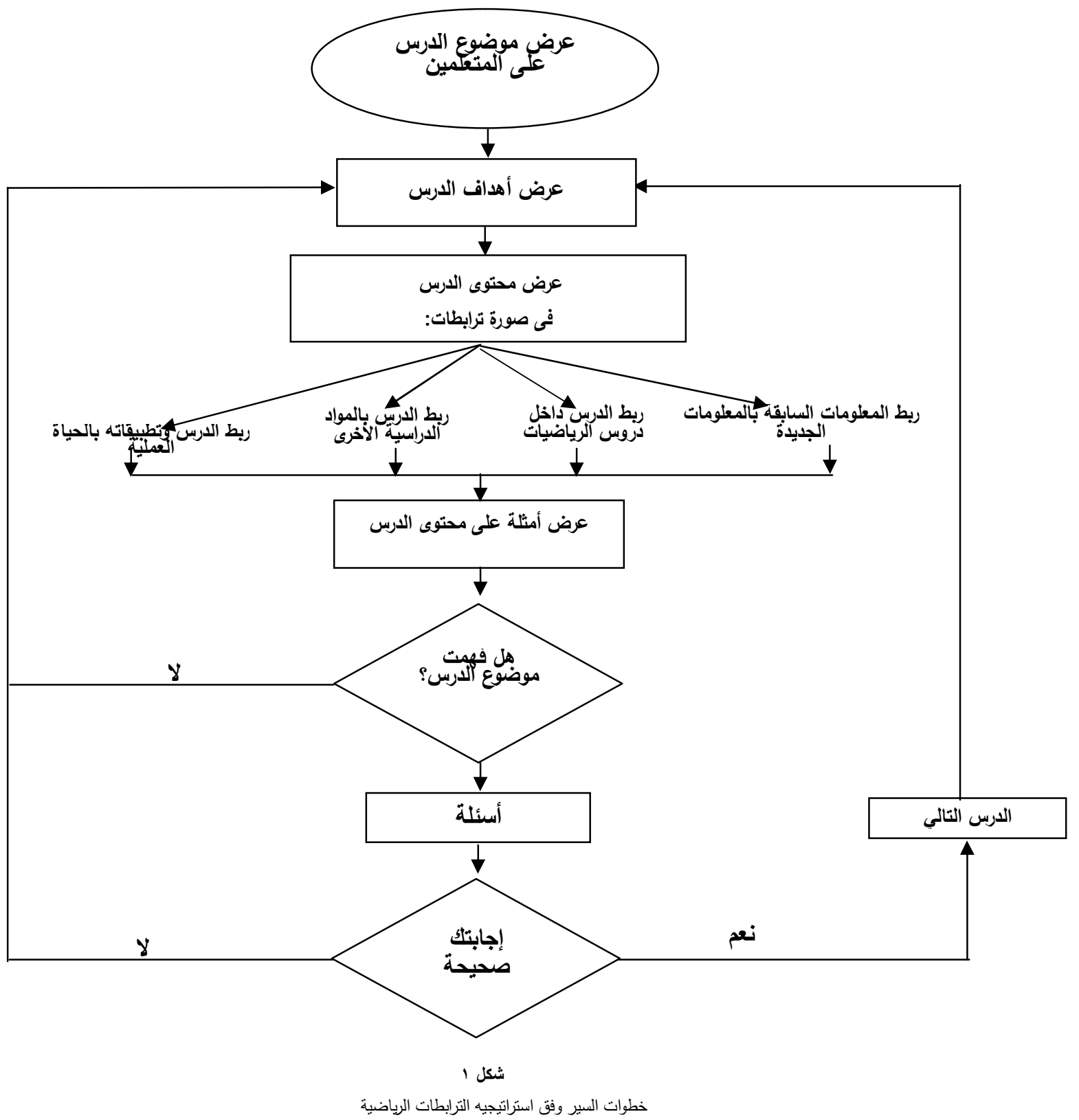




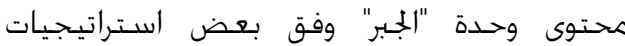

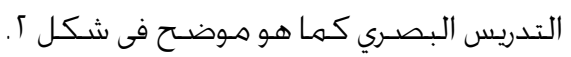

وفق بعض اسـتراتيجيات التدريس البصـري: هـن

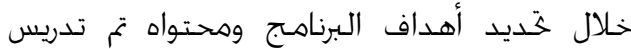

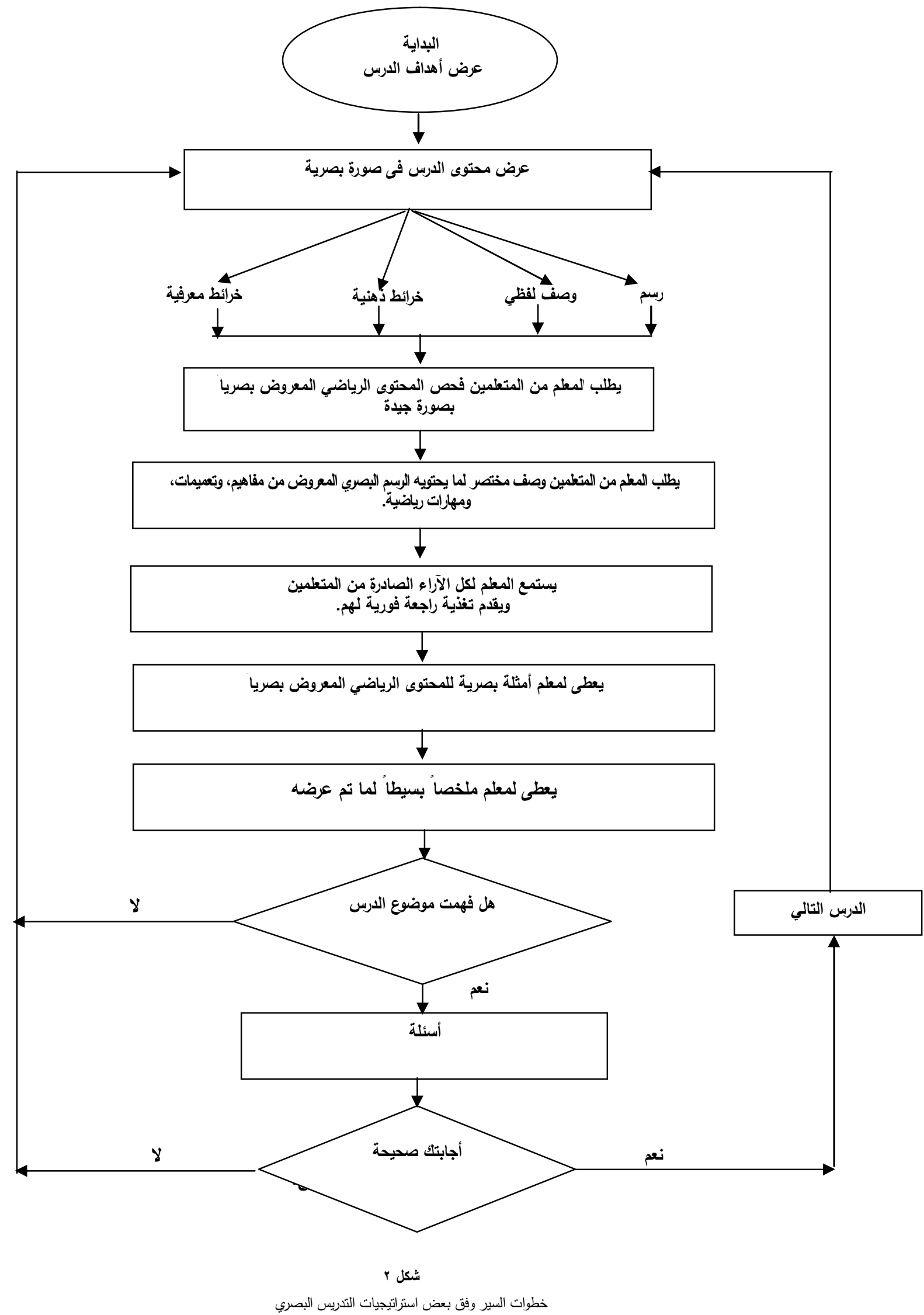


• إخبار التـلاميـذبـموضـوع الدرس وأهـدافــ.

• عرض بعض الأمثلة التى تربط الدرس بالدروس الدوس السـابقة.

• مناقشـة التلاميذ في الأمثلة المطروحـة هـن أجل الجل

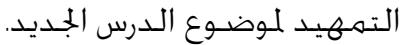

؟ - أثناء التدريس: يتهم إتباع الخطوات التالية: أ - طرح موضـوع الـرس.

ب - عـرض مـوضـوع الدرس في صـورة. • ربط اللعلومات السـابقـة بالمعلومات الجـديدة. • ربط جـوانب التعلهم المتضـمنـة في الدرس ببعضها البعض. ريته • ربط الدرس بدروس في مواد دراسية أخري. • ربط الدرس بحياة التلاهيذ العمليـة.

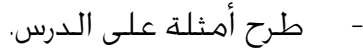

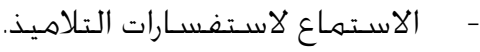

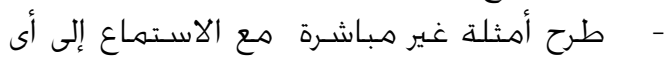

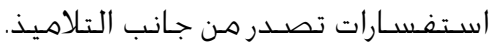
ץ - بعد التـدريس: تم تنفيذ الخطوات الآتية:

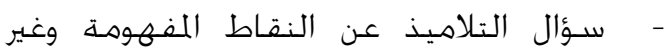
اللفهومة في الدرس.

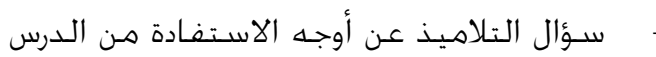

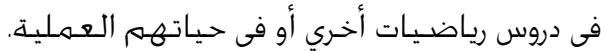

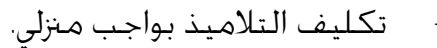
ثالثاً: دليل المعلم وفق استراتيجيه التدريس البصـري:

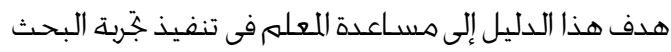

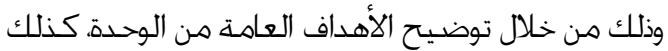

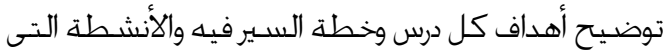
سيقوم بها المتعلم وطرق تقويم التلاميذ وقد تضـمـن

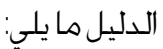
ا - قبل التدريس: يقوم المعلم بعـرض أهـداف الدرس وهناقشتهـا مـع تلاميذه.

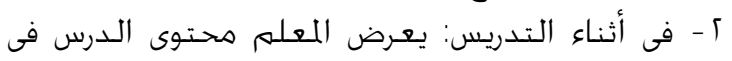

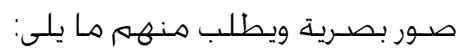

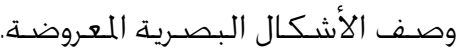

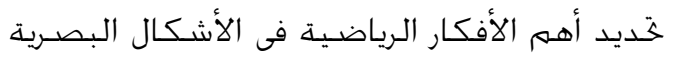
المعـروضـة. r - بعد التدريس: يقوم المعلم بعرض وصـف مختصـر

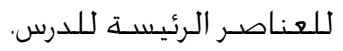
رابعًاً: إعداد أدوات القياس:

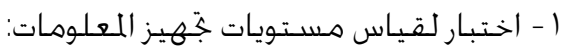

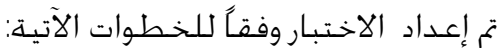

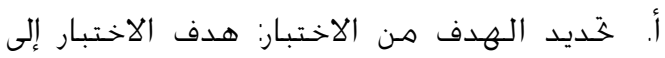

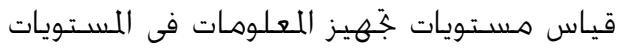

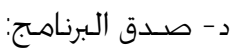

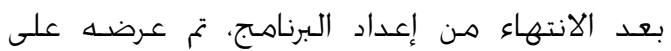

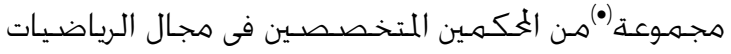

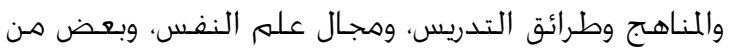

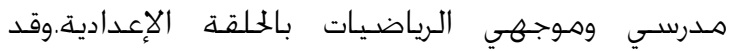

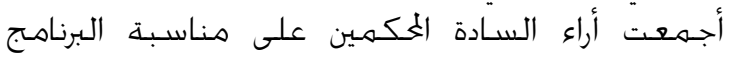
للهـدف الذي وضـع مـن أجله. هـ - التجـربة الاستـطلاعية:

تم تطبيق بعض دروس هن البرناهـج على عينة

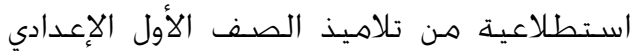

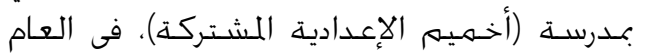

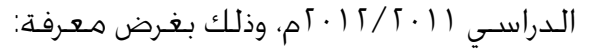
- مدى قدرة التلاميذ على التعليم والتعلم هـن

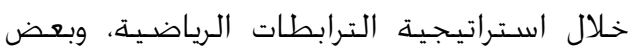

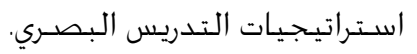
- مدى مناسبة أسـلوب طريقة عرض الدروس مع التلاميذ.

- الصعـوبات التى قـد تعـرض التطبيق على عينة البحـث النهائية.

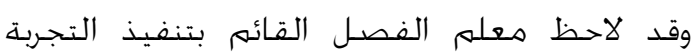

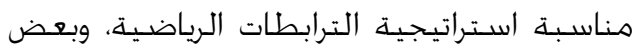

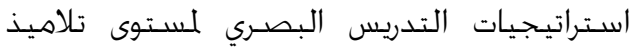

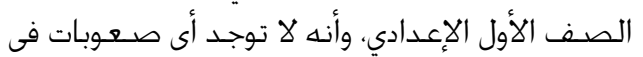

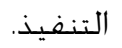

و - تقـويم اللبرنامهج:

بعد الانتهاء مـن عـملية التحكيهم تم تطبيق البرنامهج

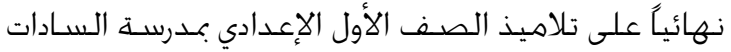

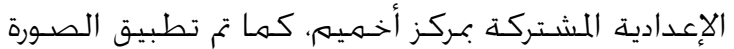

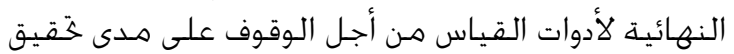

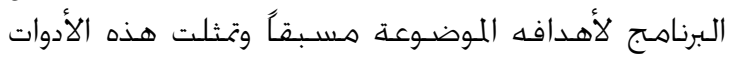

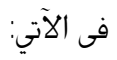
- اختبار لقياس مستويات جّهيز المعلومات. - مقياس لتقويم أنماط المعرفـة الرياضـيـة المكتوبة.

ثانياً: دليل المعلم وفق استراتيجيه الترابطات الرياضية:

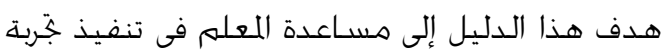

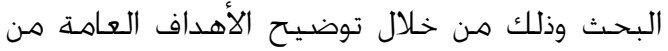
الوحدة، وكذلك توضيح أهداف كل درس وخطـة السير فيه والأنشـطة التى سـيقوم بهانها المتعلم وطرق تقويمها

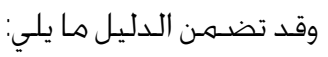
ا - قبل التدريس: يتم إتباع الخطوات التالية:

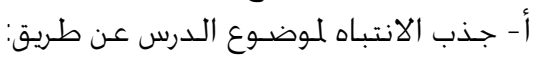

(•) عدد المحكمين V من جامعات: سو هاج، المنيا، الملك خالد 
اللكتوبة عند تلاميذ الصـف الأول الإعـدادي بمدرسـة السـادات الإعـدادية بأخسميسم.

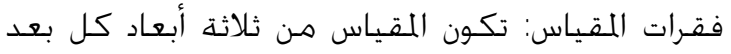
يمثل نمط من أنماط المعرفة هي:

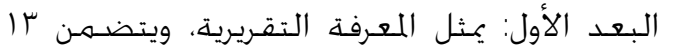
عبارة.

البعـد الثاني: يمثل المعرفة الإجرائية، ويتضـمن عبارة.

البعـد الثالث: يمثل المعرفة الشـرطية، ويتضهمن بارة عبارة. إجـمالى عبارات المقياس وب عبارة. ضبط المقياس: بعد الانتهاء مـن صـياغة فقرات

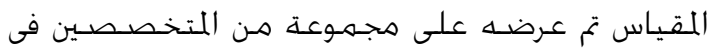

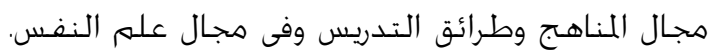

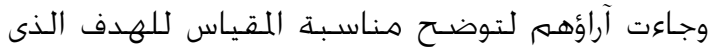

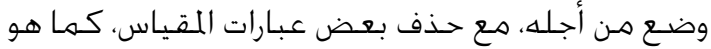

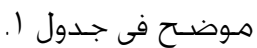
جدول المنام

البنود التى تم حذفها من المقياس وفق أراء المحكمين

\begin{tabular}{|c|c|c|}
\hline البنود المحذوفة البنة & 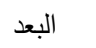 & r \\
\hline 1 - أعى تماماً مضمون أى مصطلح رياضي. & 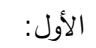 & \\
\hline r - أسنطيع تحليد عد الدفاهيم الرياضية المتضدنة فى & 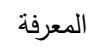 & 1 \\
\hline أى محتوى. & التقريرية & \\
\hline
\end{tabular}

1 - استخدم طرقاً رياضية ثبت نجاحها لتحديد

$$
\text { المطلوب فى النص الرياضي. }
$$

r - لدى أهداف خاصة لكل طريقة استخدمها لوناص

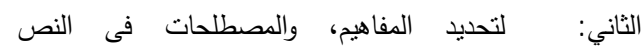

r

لإجرائية ب - لدى أهداف خاصة لكل طريقة استخدمها

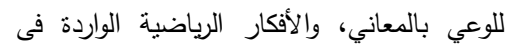

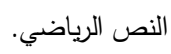

ـ - لدى أهداف خاصة لكل طريقة استخدمها.

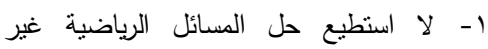

الثالث :

r المعرفة النمطية إلا إذا كنت على دراية بمسائل رياضية

الثرطية مشابهة لها.

المجموع

وبذلك يكون عدد عبارات المقياس ؟ب عبارة.

• التطبيق الاستطلاعي للمقياس: بعد تعرف آراء السـادة الغكمين تم تطبيق المقياس على على عينة

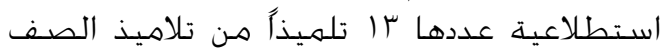

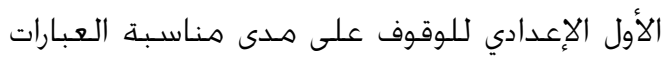

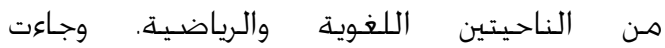

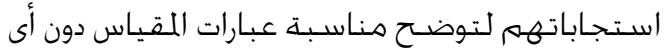
غـموض هن الناحيتـين الرياضـيـة أو اللغوية.
الثلاثة: السـطحي، والمتوسـط، والعميق في وحدة " الجـبر" عندـ تلاميـذ الصـف الأول الإعـدادي.

ب. الصـورة الأولية للاختبار: تضـمنت الصـورة الأولية

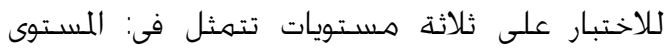

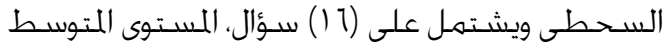

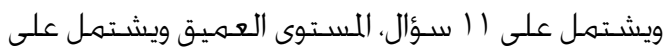

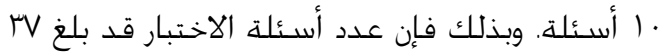

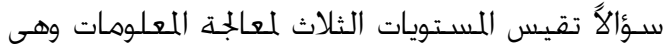
(السـطحي، المتوسـط، العميق) وذلك في وحـدة "الجبـر".

ج. ضبط الاختبار: بعـد الانتهاء مـن إعداد الاختبار، تم

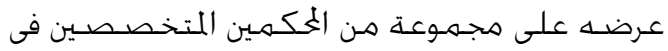

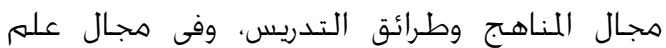

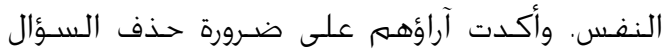

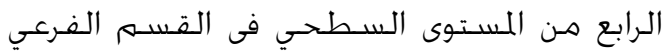

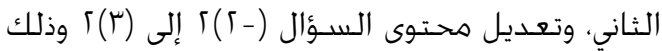

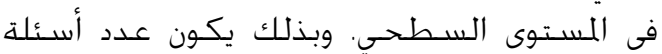

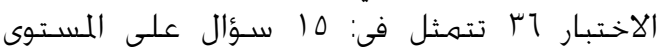

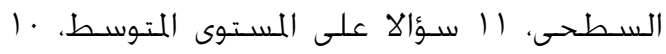

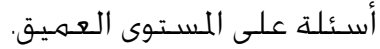

د. التطبيق الاستطلاعي للاختبار: بعد تعرف آراء

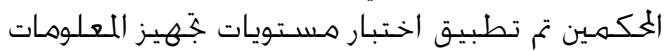

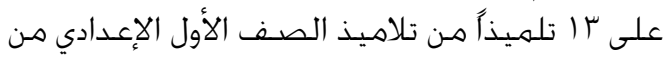

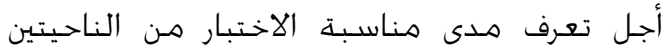

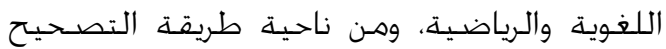

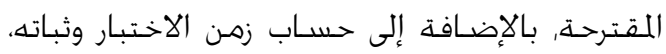

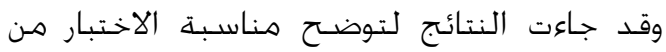
الناحيتين الرياضـيـة واللغويـة.

ه. رهن الاختبار: تم حسـاب زهـن تطبيق الاختبار عن

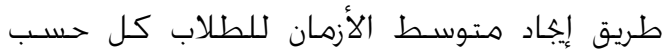

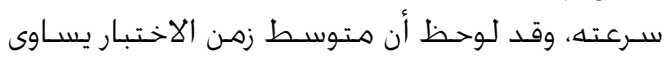
0 دقيقة تقريبًا.

و. حسـاب ثبات الاختبار: بعد القيام بعـرض الاختبار

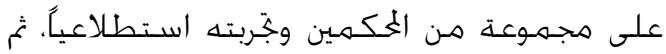

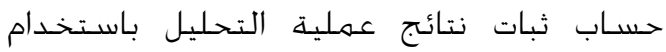
معادلة "كرونباخ" وقد وجـد أنه يساوى (1), وهـات وهو

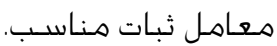

زن الصـورة النهائية للاختبار: بعد القيام بصياغة

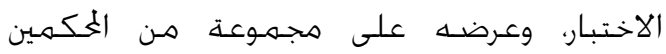

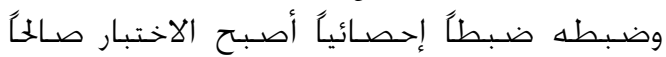
للتطبيق النهائي.

؟ - مقياس تقويم أنماط المعرفة الرياضية المكتوبة: الهدف هـن المقياس: هـدف اللقياس إلى تقويم أنماط

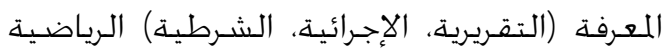




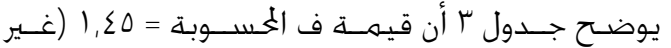

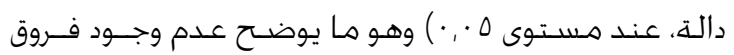

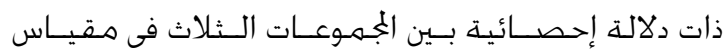
تقويم أنماط المعرفة الرياضـية المكتوبة.

سـادساً: تنفيذ جَريـة البحث: بعد توضيح الهـدف مـن التجربة لمدرس مادة الجبر الخاصـة

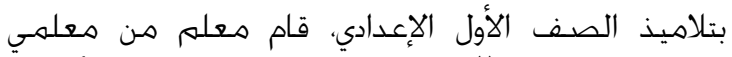

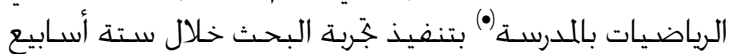

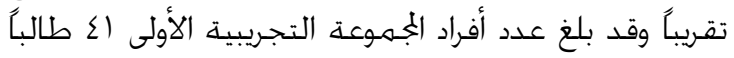

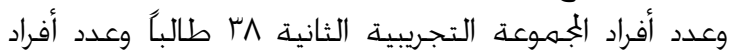
الجمهـوعة التجريبية الثالثة ·ع طالبًا.

\section{سـابعًا: التطبيق البعدي لأدوات القياس :}

بعد الانتهاء من استخـدام استراتيجية الترابطات

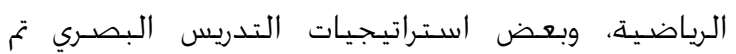

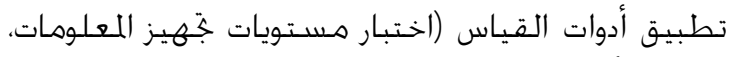

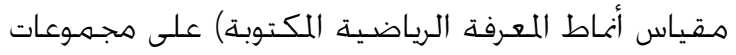

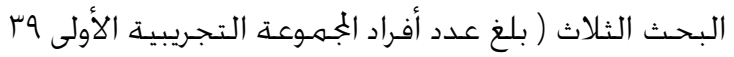

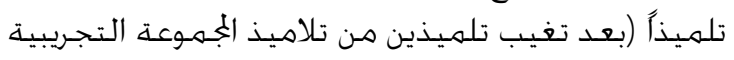

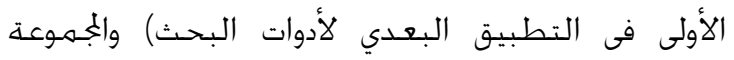

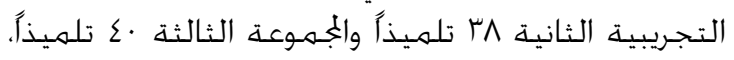
كما تم تصحيحها ورصيدها.

\section{النتائج ومناقشتها}

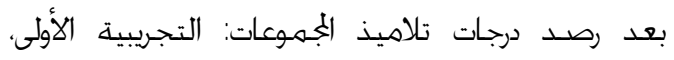

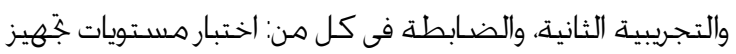

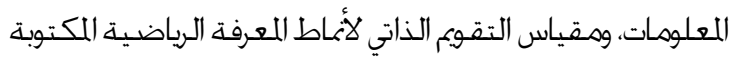

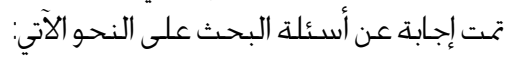
حاول البـحث الخالي الإجـابة عـن السـؤال الرئيس الآتي:

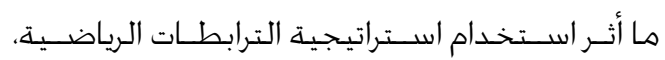

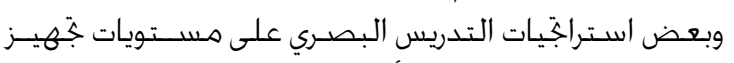

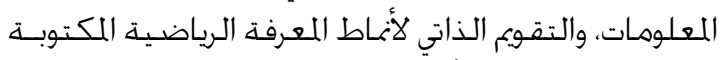

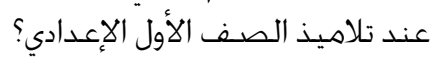

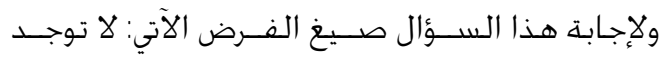

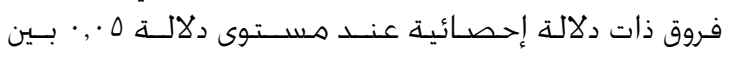

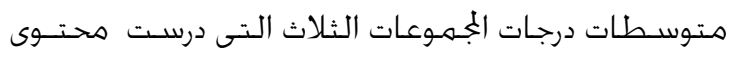

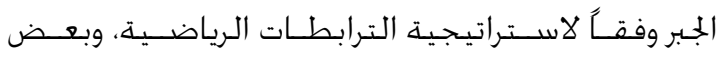

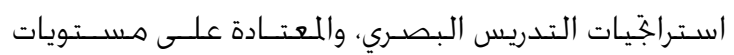

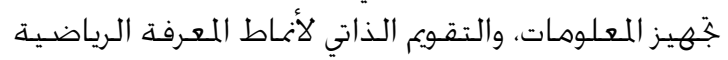

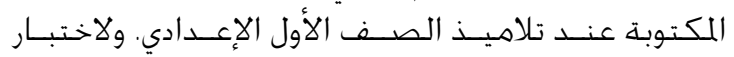

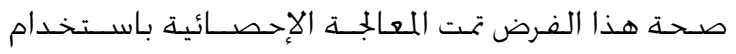

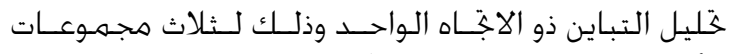

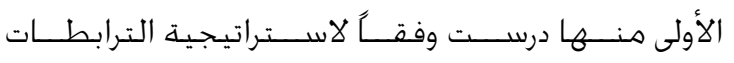

هسياب هتوسط زهـن المقياس: تم حسـاب زهـن

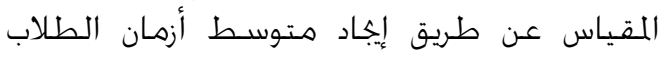

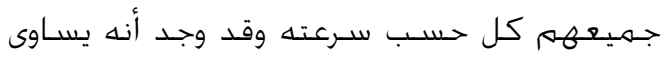
ها دقيقـة تقــريبًا.

حسـاب ثبات المقياس: بعد القيام بعرض المقياس

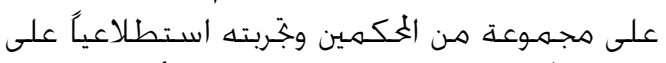

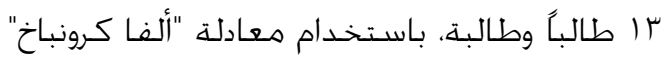
وجـد أنه يسـاوى IV, · وهو هعاهل ثبات هناسـب.

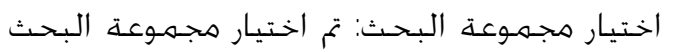

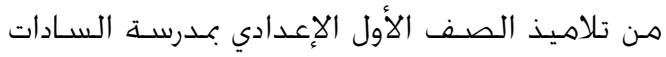

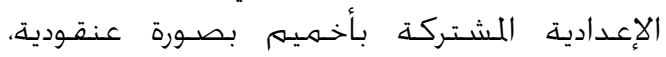

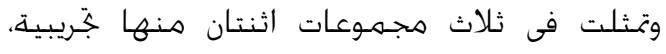

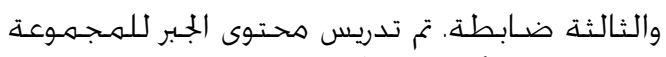

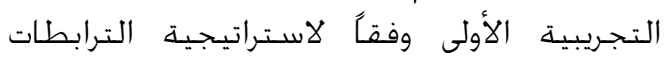

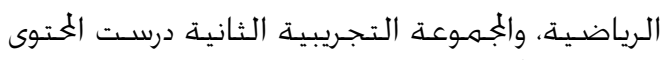

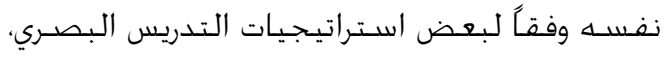

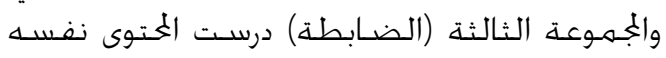

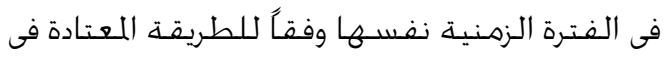
التدريس. " التطبيق القبلي لأدوات القياس: تم تطبيق أدوات

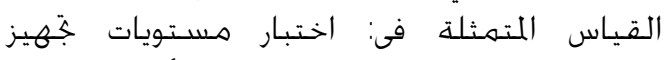

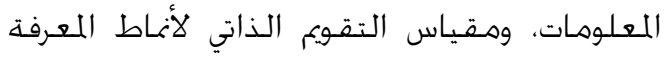

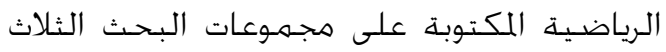

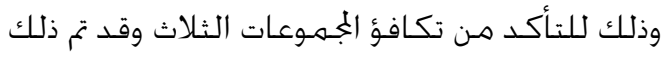

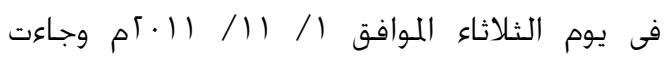

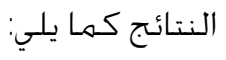

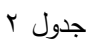

نتائج تحليل التباين فى اتجاه واحد لاختبار مستويات تجهيز المعلومات

\begin{tabular}{|c|c|c|c|c|c|}
\hline \multicolumn{6}{|c|}{ الرياضية } \\
\hline مستوى م & قيمة & متوسط & درجة & مجموع & \multirow{2}{*}{ مصدر التباين } \\
\hline الدلالة & ف & المربعات & الحرية & المربعات & \\
\hline$\cdot, 100$ & $1,9$. & $1 \cdot, \lambda 1$ & r & $r, \pi r$ & بين المجموعات \\
\hline \multirow[t]{2}{*}{ - } & - & $0, V$. & 117 & דו,ווד & داخل المجموعات \\
\hline & & & 111 & $\checkmark \wedge r, \wedge \Lambda$ & المجموع \\
\hline
\end{tabular}

يوضسح جدول † أن قيمة ف العسـوبة =·9, 1 وهي غير

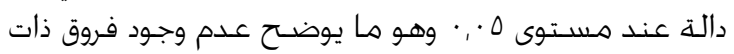

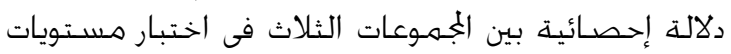
جّهيز المعلومات الرياضية.

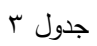

ثنائج تحليل التباين فى اتجاه واحد لمقياس تقويم أنماط المعرفة الرياضية المكتوبة

\begin{tabular}{|c|c|c|c|c|c|}
\hline مستوى الدلالة & فيمة & المربعات & لدرجة & المربعات & مصدر التباين \\
\hline ATM & $1, \leqslant 0$ & $1, \cdot r$ & $r$ & $r, \cdot T$ & بين المجموعات \\
\hline . & . &.$v 1$ & $\begin{array}{l}117 \\
111\end{array}$ & $\begin{array}{l}\text { Ar.rt } \\
\text { AE.rt }\end{array}$ & داخل المجموعات \\
\hline
\end{tabular}


الرياضـية، والأخـرى درسـت بالاسـتراتيجيات المعتادة في

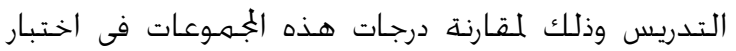

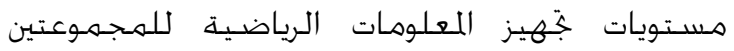
ويوضسح جدول 1 نتائج تطبيق خُليل التباين أحسادى الاجّماه.

\section{جدول 1}

نتائج تحليل الثباين الأحادي لاختبار مستويات تجهيز المعلومات الرياضية فى البع

\begin{tabular}{|c|c|c|c|c|c|}
\hline \multicolumn{6}{|c|}{ النطبيق البعدي } \\
\hline مستوى & \multirow{2}{*}{ قيمة ف } & منتوسط & درجة & مجموع & مصدر \\
\hline الدلالة & & المربعات & الحرية & المربعات & التباين \\
\hline \multirow[t]{2}{*}{$\cdot, \cdot 1$} & & $V \mid v, 09$ & 1 & $V) v, 09$ & بين \\
\hline & \multirow{3}{*}{. } & & & & (1) \\
\hline \multirow[t]{2}{*}{. } & & \multirow[t]{2}{*}{$r, 1 r$} & VV & 1740,97 & المجموعات \\
\hline & & & VA & $r T \leqslant T, 00$ & المجموع \\
\hline
\end{tabular}

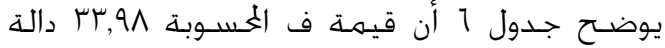

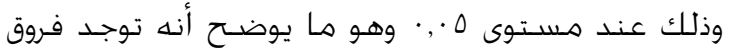

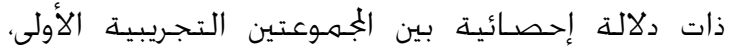
والضـابطة في التطبيق البعدي لاختبار مستـويات خجهيز

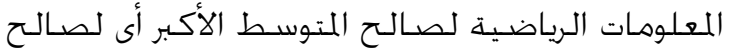

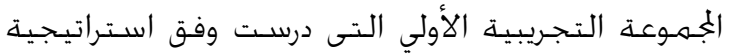

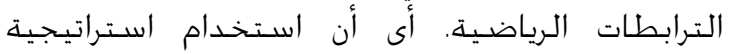

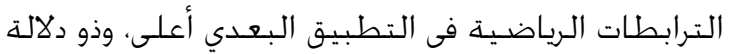

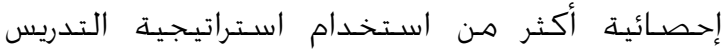

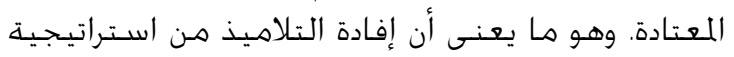

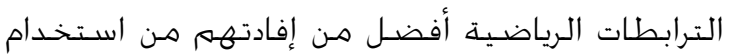

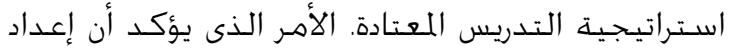

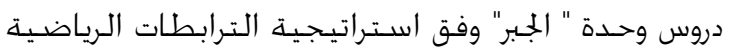

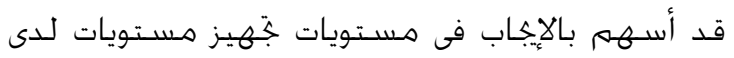
تلاميذ الصف الأول الإعـدادي.

ويرى الباحـث أن النتيجـة السـابقـة يمكـن أن ترجـع إلى:

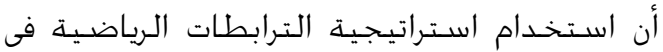

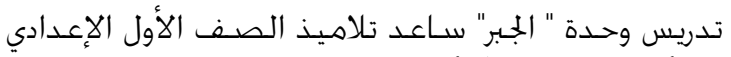

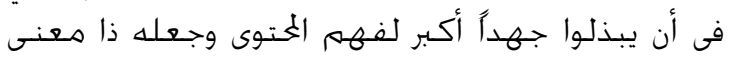

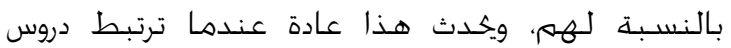

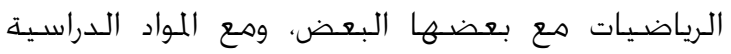

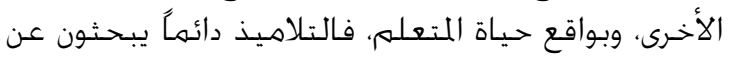

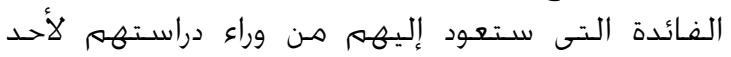

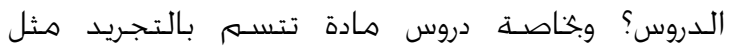

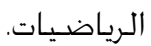

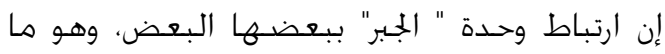

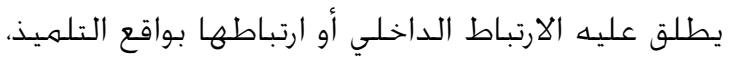

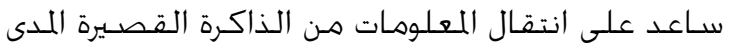

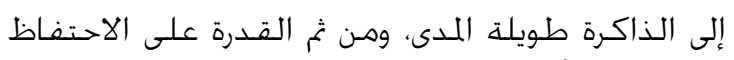

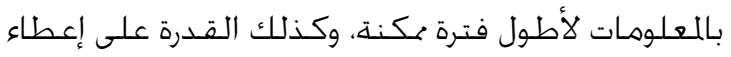

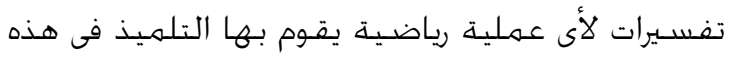

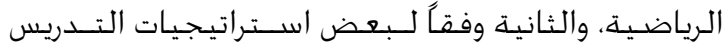

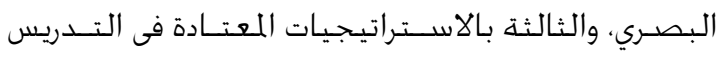

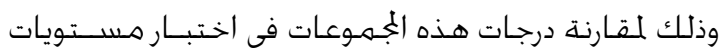

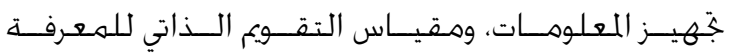

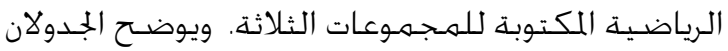
ع و ه نتائج تطبيق خُليل التباين أحسادى الاجّاه.

$$
\text { جدول ؛ }
$$

نتائج تحليل التباين ذو الاتجاه الواحد لاختبار مستويات تجهيز المعلومات الرياضية في النطبيق البعدي

\begin{tabular}{|c|c|c|c|c|c|}
\hline مستوى & قيمة ف & متوسط المربعات & الحرية & $\begin{array}{l}\text { المربعات } \\
\text { مجموبع }\end{array}$ & مصدر التباين \\
\hline$\cdot, .1$ & $* \mid v, V \varepsilon$ & ד r & r & VON,VY & بين المجموعات \\
\hline \multirow[t]{2}{*}{ • } & . & r $1, r q$ & $11 \varepsilon$ & $r \leqslant r \Lambda, 01$ & داخلموعات \\
\hline & & & 117 & $\Gamma / Q V, r r$ & المجموع \\
\hline
\end{tabular}

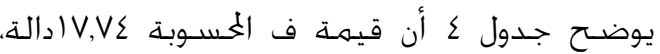

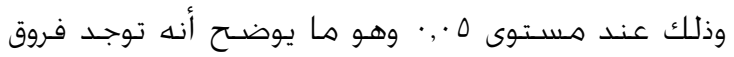

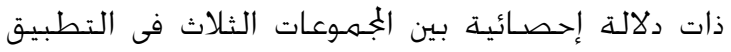
البعدي لاختبـار مســويات جُهـيز المعلوهات الرياضـيـة.

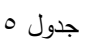

\begin{tabular}{|c|c|c|c|c|c|}
\hline مستوى & قيمة ف & متوسط & درجة & مجموع & مصدر \\
\hline الدلالة & المحسوبة & المربعا & الحرية & المربعا & التباين \\
\hline$\cdot, \cdot 1$ & $* 11,10$ & $7, r$. & r & $|Y, \varepsilon|$ & المجموعات \\
\hline & - & $\cdot, 07$ & $11 \leq$ & Tr, $\leqslant 0$ & المجموعات \\
\hline & & & 117 & Vo, AT & المجموع \\
\hline
\end{tabular}

نتائج تحليل التباين ذو الاتجاه الواحد لمقياس تقويم أنماط المعرفة الرياضية

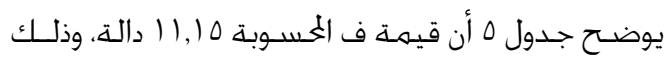

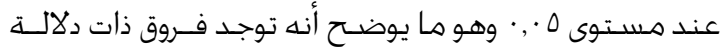

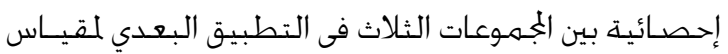

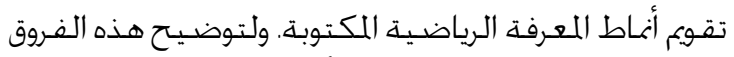
بين الجُموعات الثلاث تتم إجابة الأسئلة الآتية:

إجابة السـؤال الفـرعي الأول: ما أثر اسـتخدام

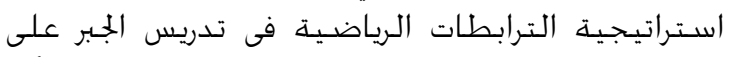

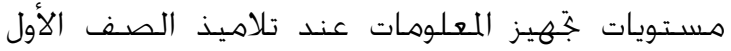

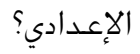

ولإجابة هـذا السـؤال صـيخ الفـرض الآتي: لا يوجـد فـرق

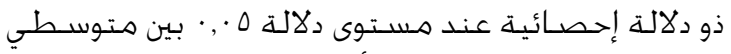

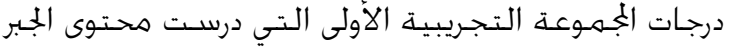

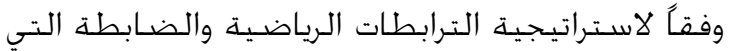

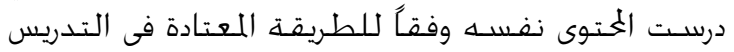
فى التطبيق البعدي لاختبار مسـتويات جَهيز المعلومات.

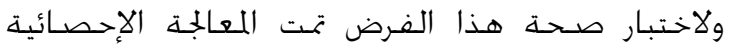

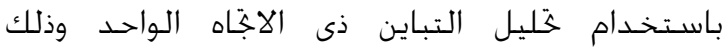

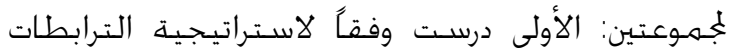


والضـابطة في التطبيق البعدي للقياس تقويم أنماط

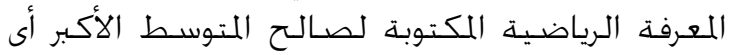

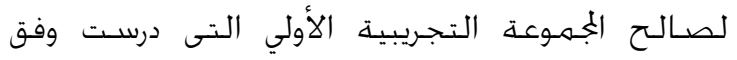
استراتيجية الترابطات الرياضية.

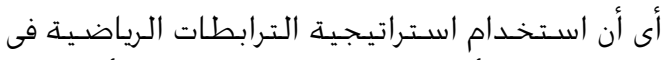

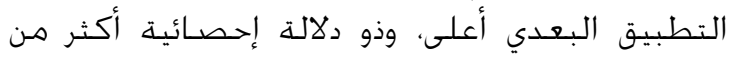

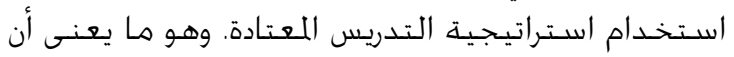

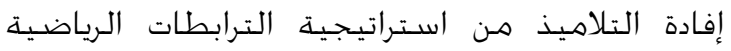

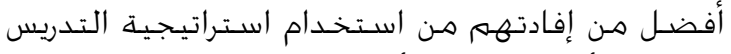

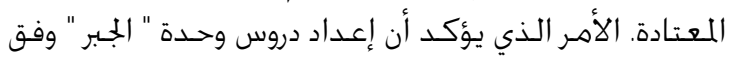

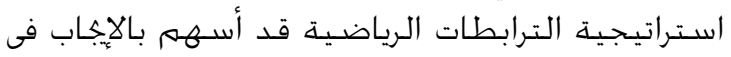

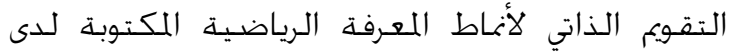
تلاميذ الصف الأول الإعدادي.

ويرى الباحث أن النتيجة السابقة يمكن أن ترجع إلى:

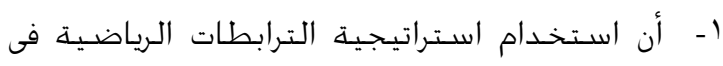

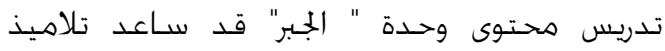
الصف الأول الإعدادي على الربط بين المبرة المفاهيم.

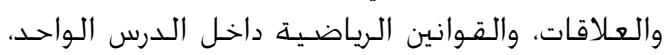

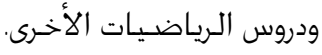

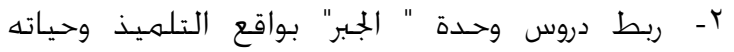

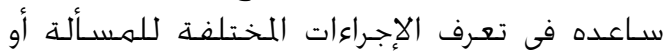

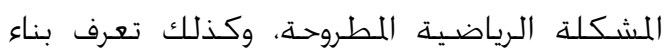
المشكلة وتراكيبها.

r- ربط محتوى وحدة "الجبر" بواقع حياة المتعلم ساعد الإسد

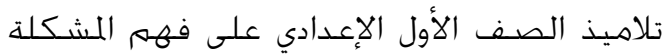

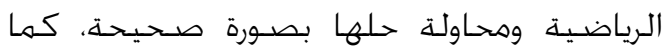
سـاعده في إعطاء مبررات للحل الذي تم الخلوص إليه.

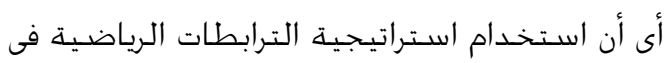

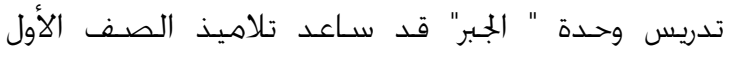

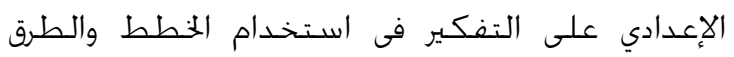

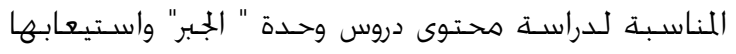

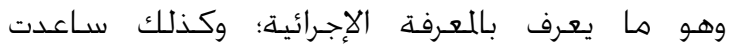

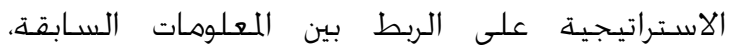

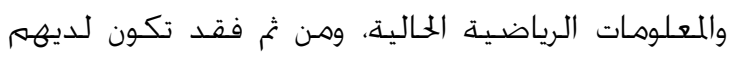
وعى بالعرفة الرياضية وهو ما يطلق عليه بالمعرفة التهاية

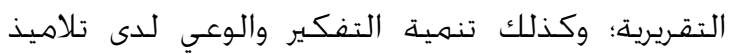

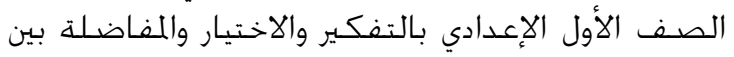

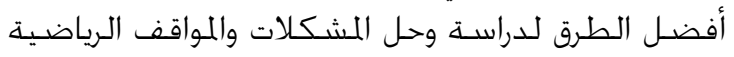

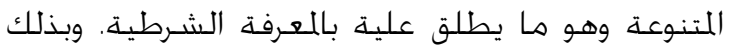

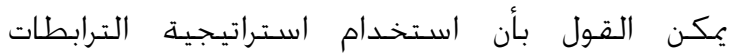
الرياضية قد سـاعد بفعالية في التقويم الذاتي لأنماط التراط الععرفة الرياضية المكتوبة.

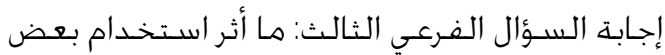

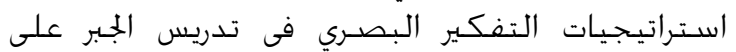

المرحلة، ونتيجة لذلك يمكن القول بأن استراتيجية

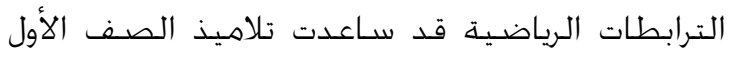

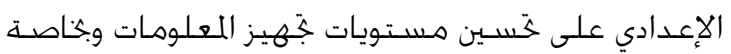

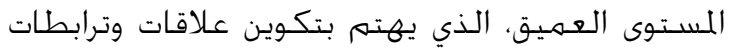
بين ما يقوم التلميذ بدراسته داخل الخهجرة الدراسية.

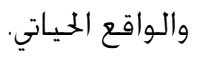

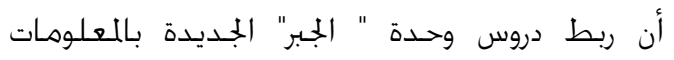

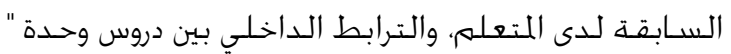

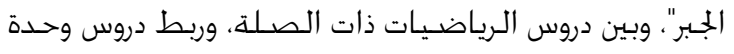

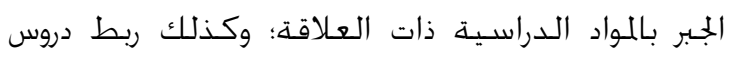

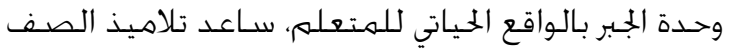

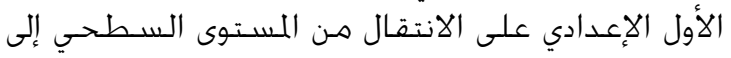

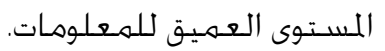

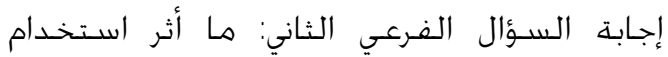

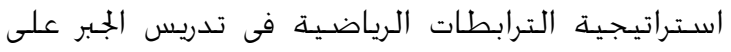

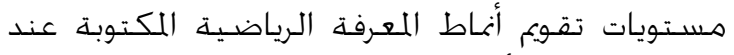
تلاميذ الصف الأول الإعدادي؟

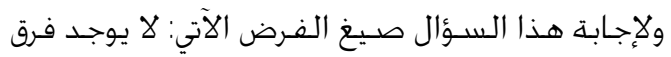

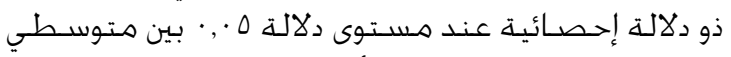

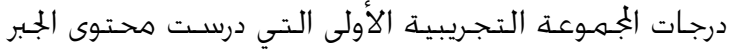

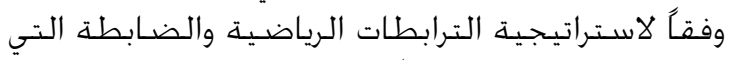

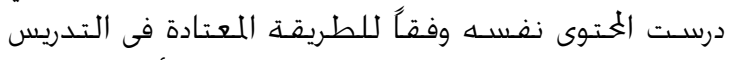
في التطبيق البعدي لمقياس التقويم الذاتي لأنماط المعرفة فئة التربسة الرياضية المكتوبة.

ولاختبار صـحة هذا الفرض تمت المعالجة الإحصائية

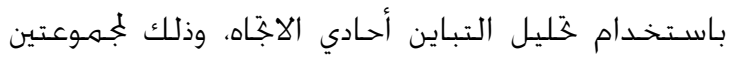

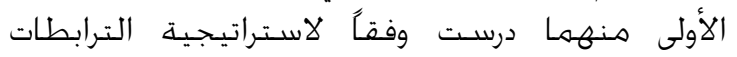

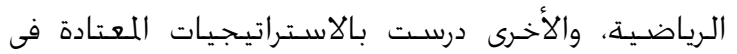

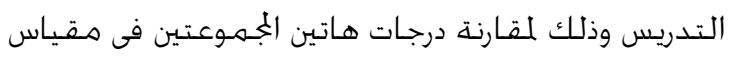

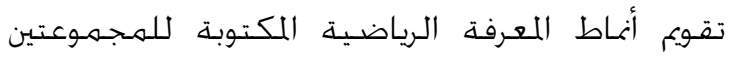

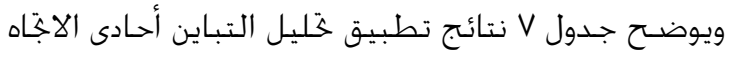
التى درست وفق استـراتيجية الترابطات الرياضية.

$$
\text { جدول vis }
$$

نتائج تحليل النباين الأحادي فى مقياس تقويم أنماط المعرفة الرياضية

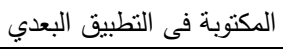

\begin{tabular}{|c|c|c|c|c|c|}
\hline الدسلةى & قيمة ف & منوسط المربعات & الحرية & المربعات & التباين \\
\hline$\cdot, \cdot 1$ & $1 \wedge, V T$ & $11, \leqslant 9$ & 1 & $11, \leqslant 9$ & بين \\
\hline \multirow[t]{2}{*}{. } & . & $\cdot, 71$ & VV & $\varepsilon V, r \leq$ & داخل \\
\hline & & & VA & $O \Lambda, V T$ & المجموع \\
\hline
\end{tabular}

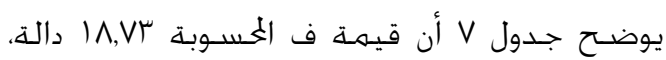

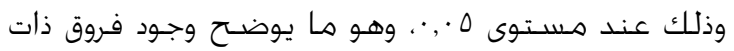
دلالة إحصائية بين الجموعتين التجريبية الأولى. 
1- أن استخـدام بعض اسـتراتيجيات التدريس البصـري

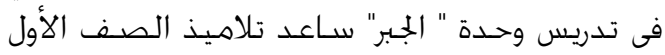

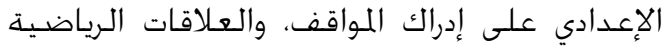

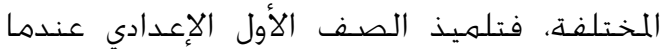

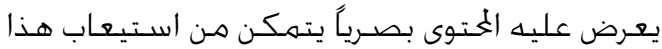

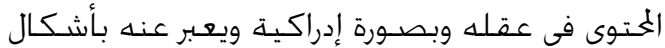

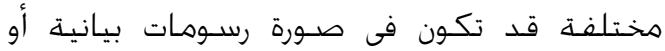

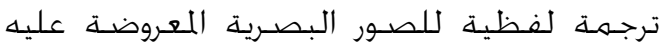

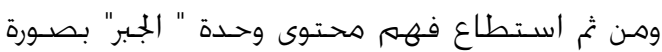
جيدة. r- يعد استخدام بعض استراتيجيات التدريس تلامبر

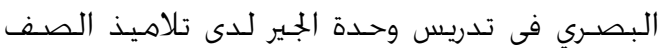

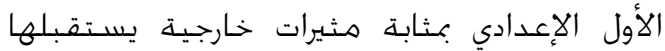

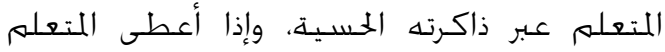
اهتماماً وانتباهاً لبعض هذاته العزه المعلومات فإنها

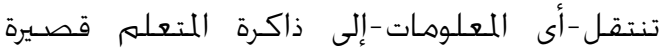

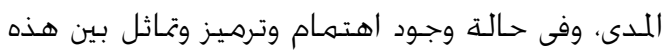
المعلومات الجديدة، وبين معلوهات المهات موجودة مسبقاً

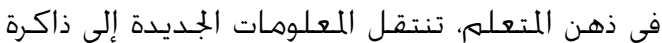

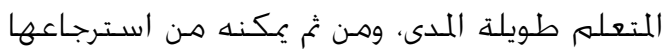

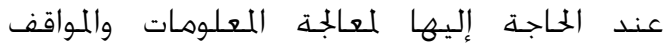
الرياضية اللطروحة.

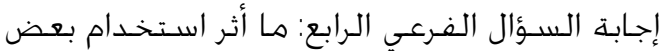

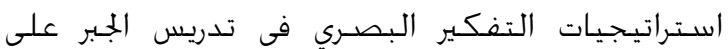

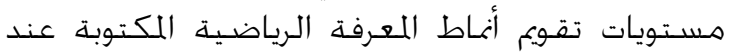

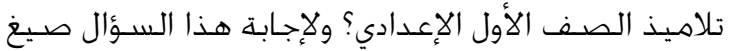

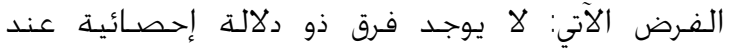

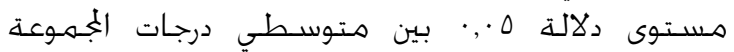

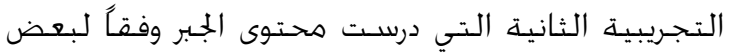

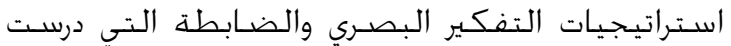

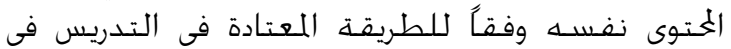

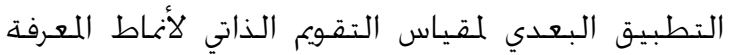
الرياضية المكتوبة.

ولاختبار صـحة هذا الفرض تمت العـالجة الإحصـائية

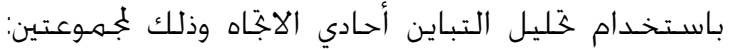

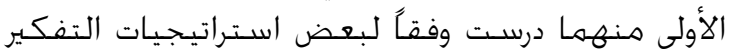

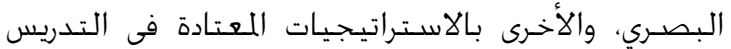

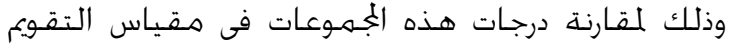

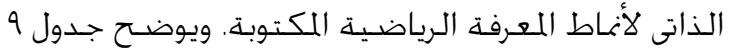
نتائج تطبيق خُليل التباين أحادى الاجّاه.

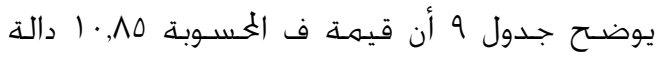

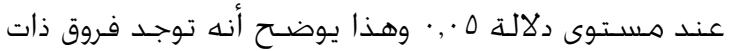

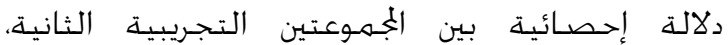
والضابطة في التطبيق البعدي للقياس تقويم أنماط الناطي

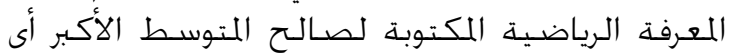

مستويات جَهيز المعلومات عند تلاميذ الصـف الأول

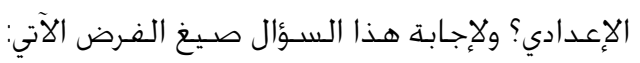

لا يوجد فرق ذو دلالة إحصـائية عند مستوى دلالة ه·, ب بين متوسطي درجات الجمهوعة التجريبية الثانية

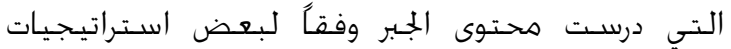

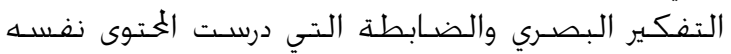

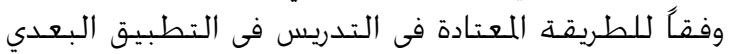

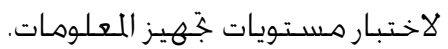

ولاختبار صحـة هذا الفرض تمت المعالجة الإحصائية

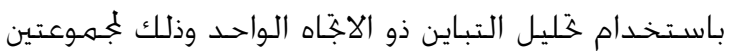

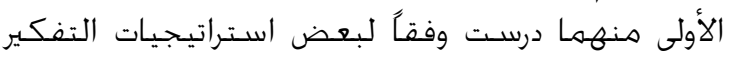

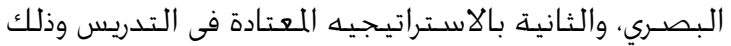

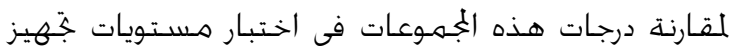

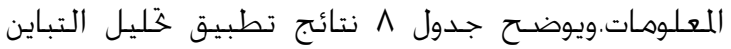

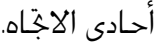

\section{جدول 1}

نتائج تحليل التباين ذو الاتجاه الواحد فى اختبار مستويات تجهيز المعلومات الرياضية فى التطبيق البعدي

\begin{tabular}{|c|c|c|c|c|c|}
\hline مستوى & قيمة ف & منوسط المربعات & الحرية & المربعات & مصدر \\
\hline$\cdot, \cdot .1$ & $r r, r q$ & ro.,T & 1 & ro., Th & المجموعاتت \\
\hline \multirow[t]{2}{*}{. } & . & $10, .0$ & $V_{T}$ & $11 \leq \leqslant, 10$ & المجموعات \\
\hline & & & VV & $1 \leqslant 9 \leqslant, \wedge r$ & المجموع \\
\hline
\end{tabular}

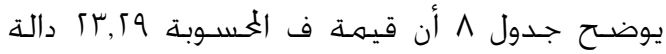

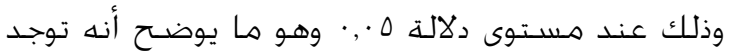

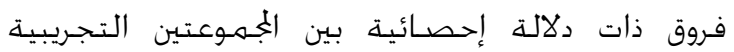

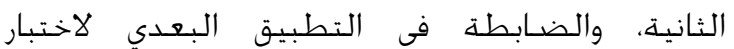

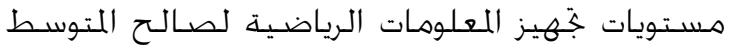

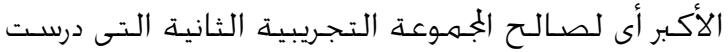

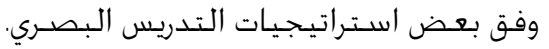

أى أن استخـدام بعض اسـتراتيجيات التدريس تلـيس

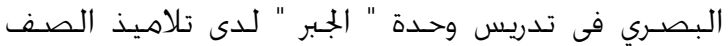

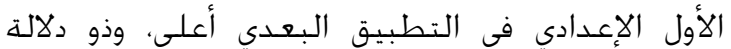

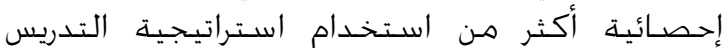

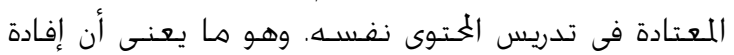

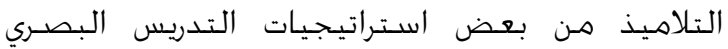

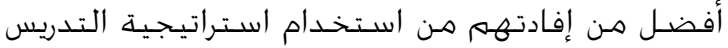

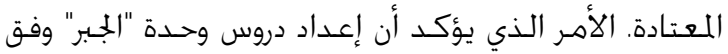

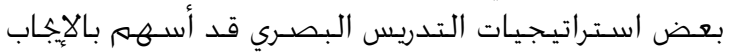

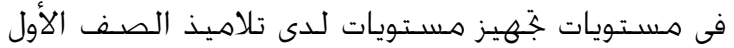

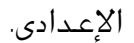

ويرى الباحث أن النتيجة السابقة يمكن أن ترجع إلى: 
إجـابة السـؤال الفـرعي الخامسس: أي من اسـتراتيجية

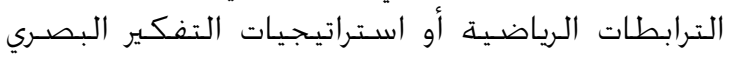

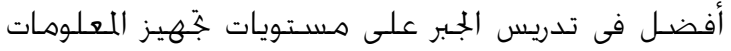

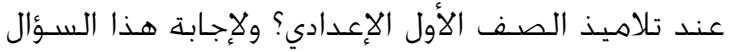

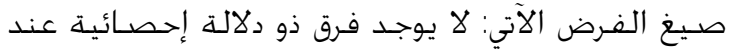

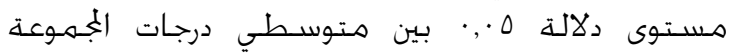

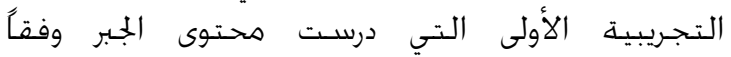

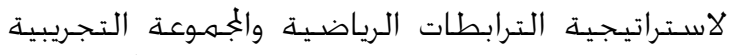

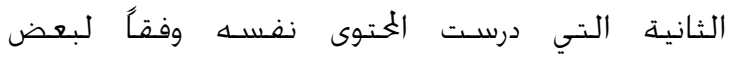

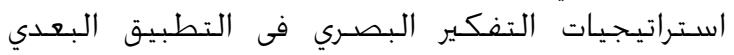
لاختبار مسـتويات جتهيز المعلوهات.

ولاختبار صحـة هذا الفرض تمت المعالجة الإحصائية

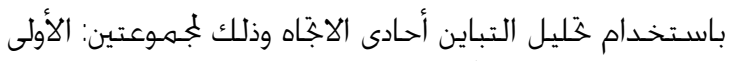

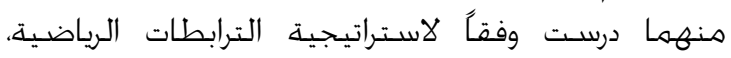

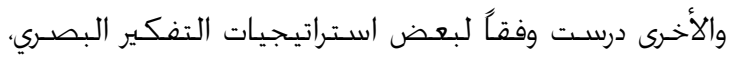

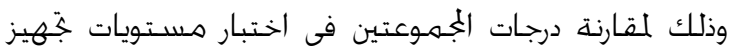

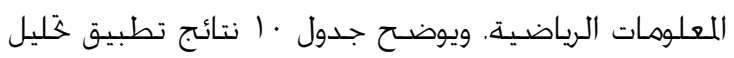
التباين أحادى الاجّاه.

$$
\text { 1. جدول }
$$

نتائج تحليل التباين الأحادي فى اختبار مستويات تجهيز المعلومات الرياضية فى ،

\begin{tabular}{|c|c|c|c|c|c|}
\hline \multicolumn{6}{|c|}{ التطبيق البعدي } \\
\hline الدلالة & قيمة ف & منوسط المربعات & الحرية & المربعات & مصدر التباين \\
\hline., $1 \leq$ & $r, 19$ & ד1, $\varepsilon$. & 1 & $71, \varepsilon$. & بين \\
\hline . & . & $r \wedge, \cdot q$ & vo & $r 1.7,91$ & داخل \\
\hline & & & VY & $r \mid r \lambda, r$ & المجموع \\
\hline
\end{tabular}

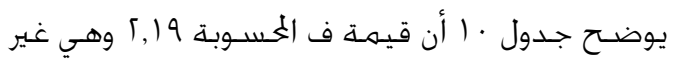

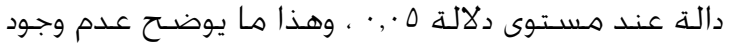

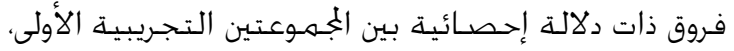

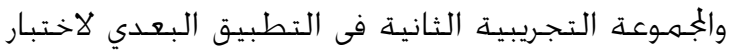
هسـتويات جنهـيز المعلومهات الرياضـيـة.

أى أن قدرة تلاميذ الجمهوعة التجريبية الأولى علي

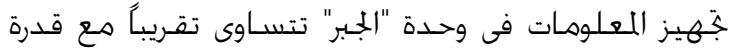

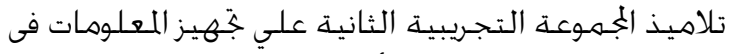

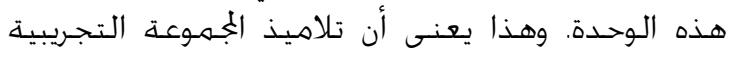

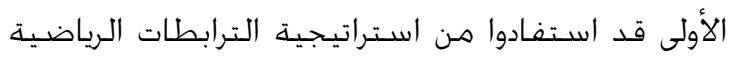

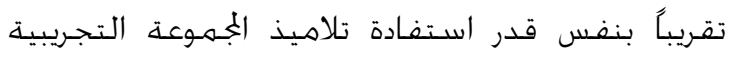

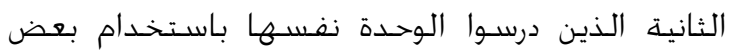

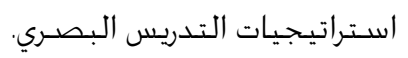

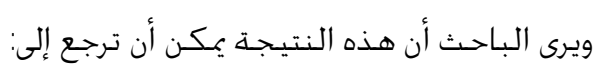
ا - أن استخــدام اسـتراتيجية الترابطات الرياضـية،

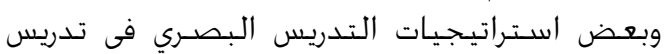

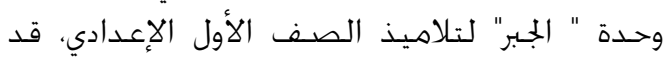

وفق

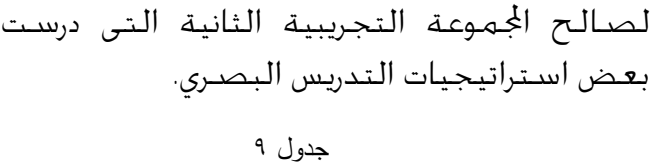

نتائج تحليل التباين الأحادي فى مقياس تقويم أنماط المعرفة الرياضية المكتوبة فى النطبيق البعدي فئين

\begin{tabular}{|c|c|c|c|c|c|}
\hline الدستلة & قيمة ف & المربعات & الحرية & المربعات & مصدر \\
\hline$\cdot, \cdot r$ & $1 \cdot, 10$ & $7, Y \leq$ & 1 & $T, Y \leq$ & بين \\
\hline \multirow[t]{2}{*}{. } & . & $\cdot, 01$ & VI & $\{r, v\}$ & دالخمل \\
\hline & & & VV & $\leqslant 9,90$ & المجموع \\
\hline
\end{tabular}

أى أن اسـتخـدام بعض اسـتراتيجيات التـريس

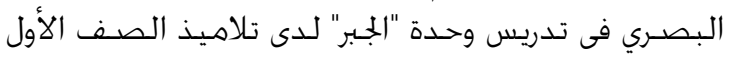

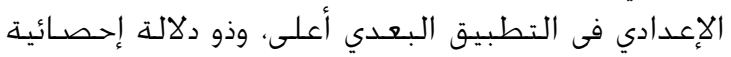

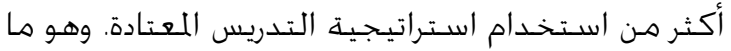

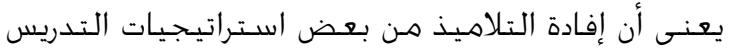

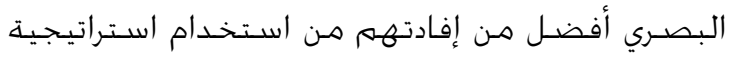

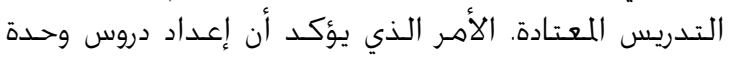

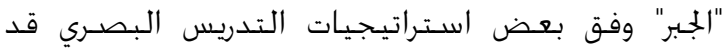

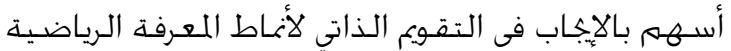

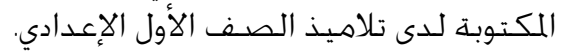

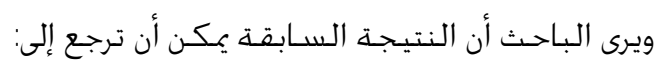

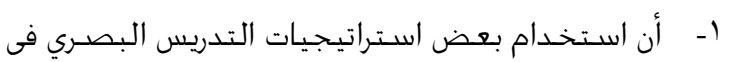

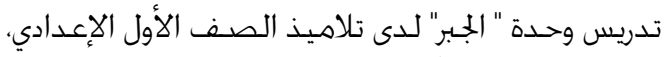

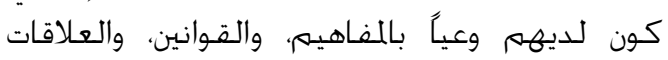

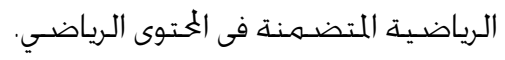

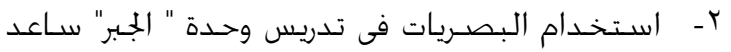

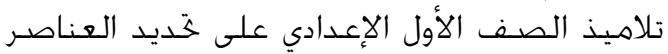

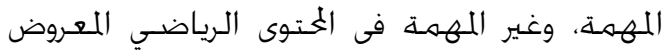

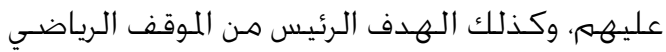
المطروح عليهم: وكنهم

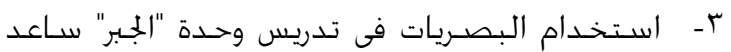

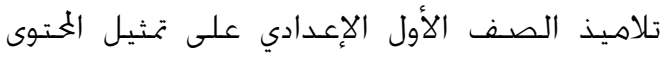

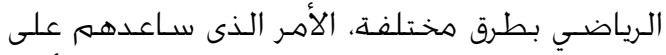

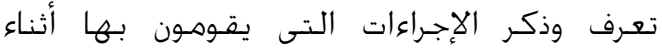

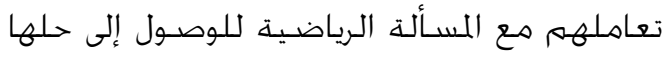
بصـورة صسحيحـة. ع - أن اسـتخـدام بعض اسـتراتيجيات التـريس البصـري

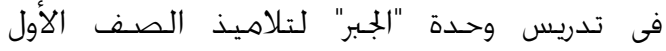

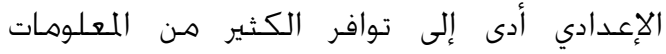

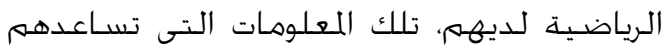

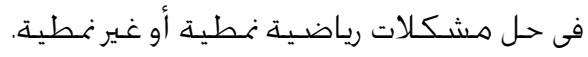


ولإجابة هذا السؤال صيخ الفرض الآتي: لا يوجد فرق

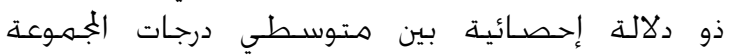

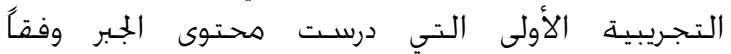

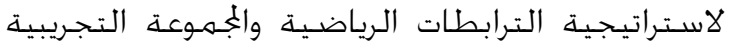

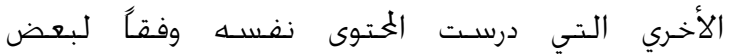

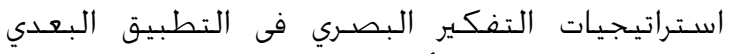

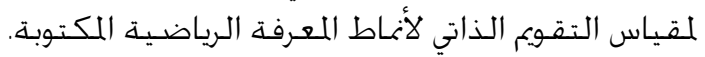
ولاختبار صحـة هذا الفرض تمت العـالجة الإحصـائية

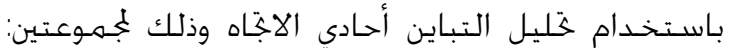

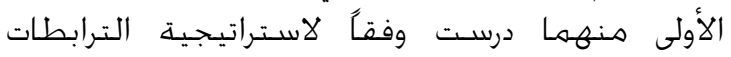

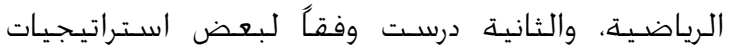

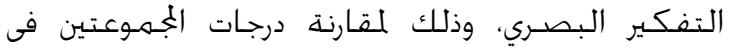

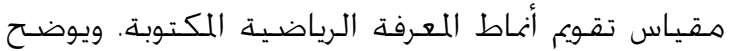
جدول / النتائج تطبيق ختليل التباين أحادى الاجناه.

$$
\text { جدول 11 }
$$

نتائج تحليل الثباين الأحادي فى مقياس تقويم أنماط المعرفة الرياضية المكتوبة

\begin{tabular}{|c|c|c|c|c|c|}
\hline \multicolumn{6}{|c|}{ فى التطبيق البعدي } \\
\hline 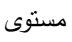 & قيمة & متوسط & درجة & 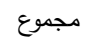 & \multirow{2}{*}{ مصدر التباين } \\
\hline الدلالة - مالة & ف ف & المربعات & الحرية & المربعات & \\
\hline •, Yr & 1,07 & $\cdot, \mathrm{V}_{0}$ & 1 & $\cdot$, Vo & بين المجموعات \\
\hline \multirow[t]{2}{*}{. } & - & $\cdot$, • ^ & vo & $r 0,90$ & \\
\hline & & & $V_{T}$ & $r \Psi, v$. & المجموع ل \\
\hline
\end{tabular}

يوضح جدول / ا أن قيمة ف الخسـوبة 1,01 غير دالة.

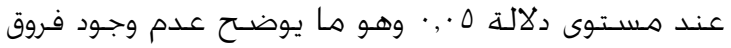
ذات دلالة إحصائية بين الجهموعتين التجريبية الأولى فئ.

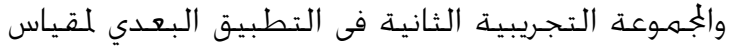

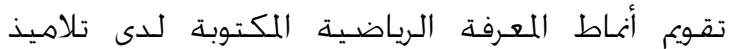
الصف الأول الإعدادي.

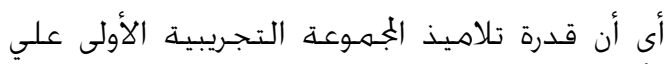

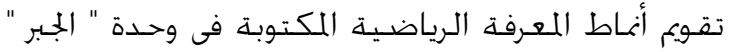

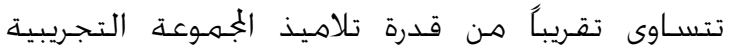

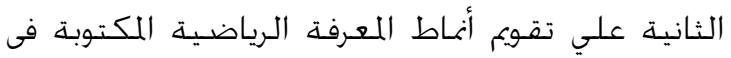

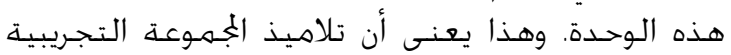

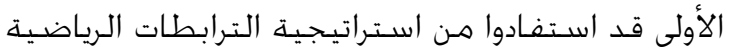

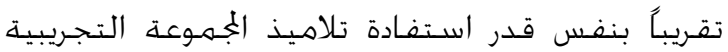

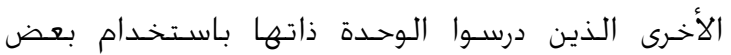
استراتيجيات التدريس البصري.

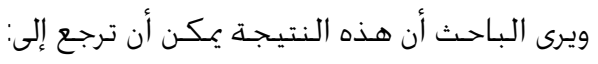

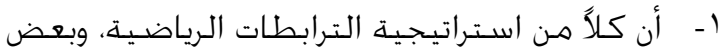

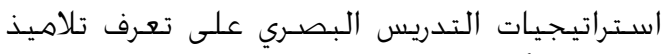

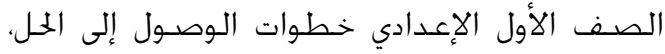

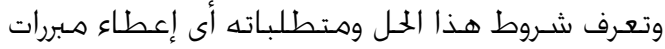

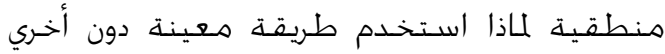
للوصـول إلى الحل.
أسهـهم في خسـين قدرة التلاميذ على إدراك شكل

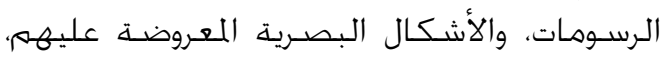

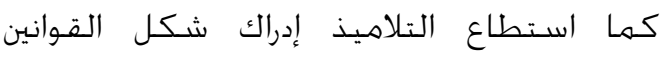
الرياضية في وحـدة "الجبر".

r- سـاعد استخدام استراتيجية الترابطات الرياضية،

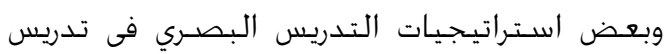

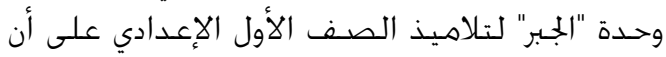

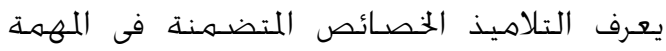

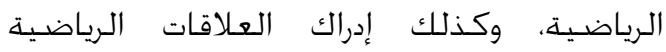

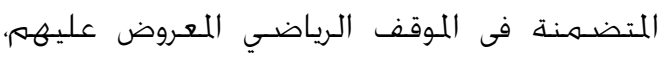

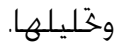

r- ساعد تقديم المعلومات بشكل منظم في كل من التر

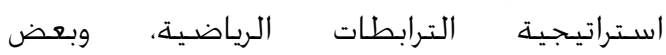
استراتيجيات التدريس البصـري، تلاميذ الجُمهوعتين على تذكر المعلومات وإيجاد العلاقات الرياضية بين الماتين جوانب التعلم المختلفة والمتمثلة في: المفاهيم. والتعميمات، والمهارات الرياضية المختلفة.

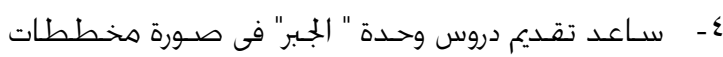

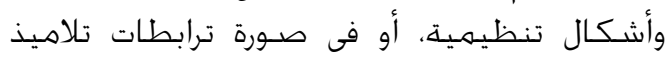

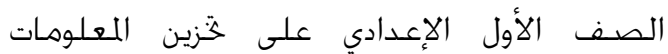

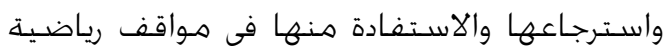

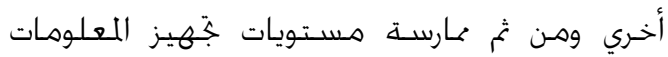
بمستوياتها الثلاث: السطحي، والمتوسط، والعميق. 0- عند استخـدام استراتيجية التدريس البصـري في

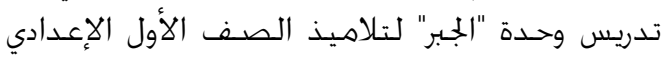

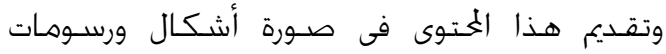
بصرية، يخاول المتعلم تكوين علاقات ترابطية بين الماتين

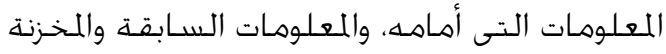

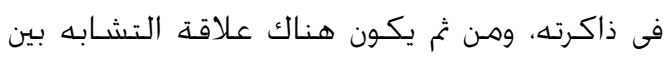
هذه الاستراتيجية، واستراتيجيه الترنية الترابطات

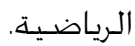

وقد يرجع السبب في هذه النتيجة إلى المعلم ذاته:

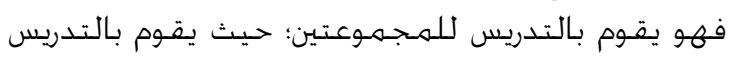

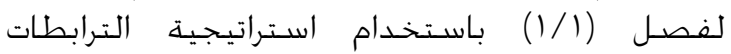

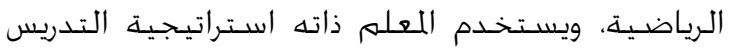

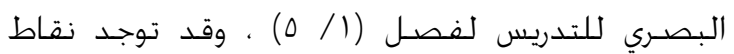

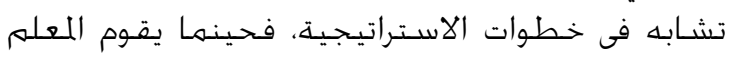

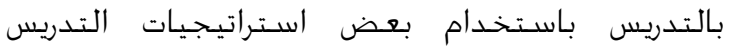

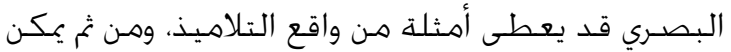

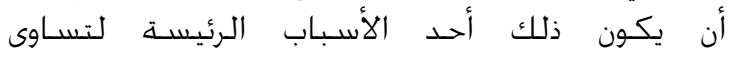

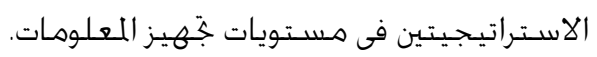

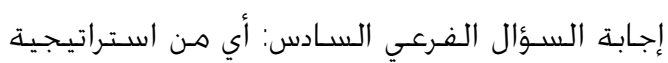

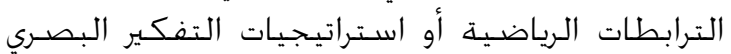

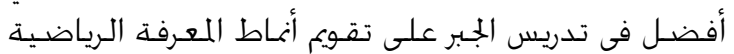

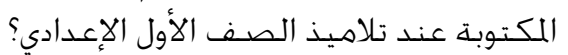


المعلومات وهى نسبة كبيرة، والنسبة الباقية ترجع لعوامل أخرى متنوعة، منها الخلفية الدراسية، وبيئة الطلاب.

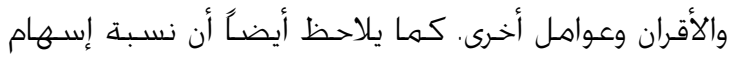

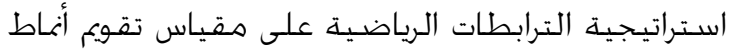

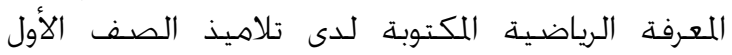
الإعدادي يساوى · م\% وهى نسبة كبيرة أيضًاً.

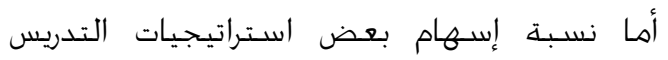

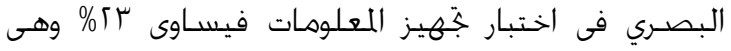

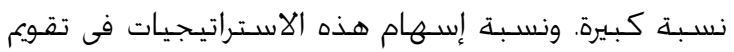

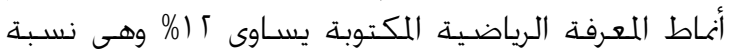
كبيرة أيضًاً.

\section{توصيات الدراسة:}

بناءً على نتائج البحث الحالي يمكن التوصية بالآتي: 1- إعادة تنظيم محتوى كتب الرياضيات بالمرحلة الإعدادية

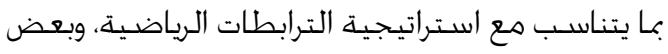
استراتيجيات التدريس البصـري. r- تدريب معلمي المرحلة الإعدادية على كيفية استخدام

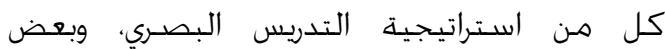
استـراتيجيات التدريس البصـري. r- عدم الاعتماد على الاختبارات التحصيلية في تقويم المعرفة الرياضية المكتوبة، والاعتماد على مقاييس الإنس تقيس الفهم العميق للمعرفة الرياضية.

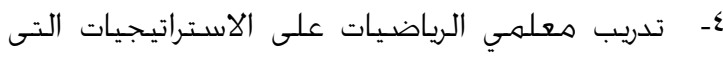

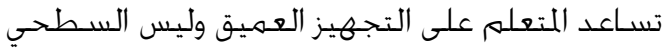
للمعرفة الرياضية. 0ـ أن يراعى معلمو الرياضيات بالمرحلة الإعدادية المستويات المختلفة لتجهيز المعلومات عند تلاميذ الإيذاريذ الصف الأول الإعدادي.

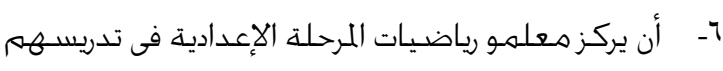

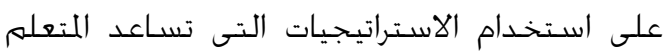

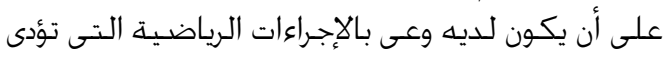
به إلى إنجاز المهمة الرياضية.

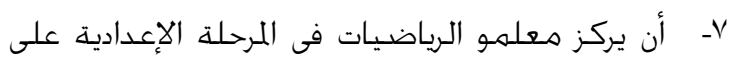

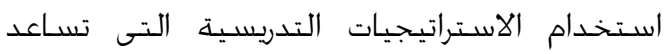

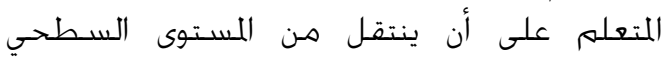
للمعلومات، إلى المستوى العميق.

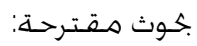

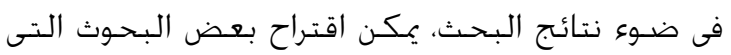
يمكن أن تكون اهتداداً للبحن البحث الحالي:

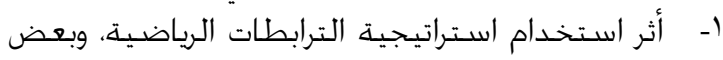

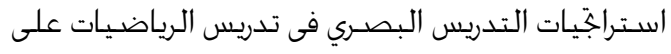

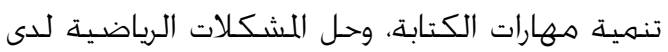
تلاميذ الصف الأول الإعدادي. r- أن استخدام استراتيجية الترابطات الرياضية،

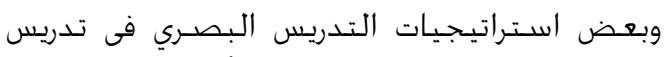

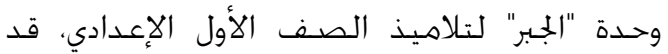

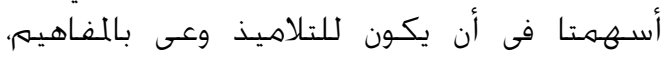
والقوانين، والعلاقات الرياضية، وكذلك تعرف علات بلاقة هذه القوانين بالقوانين ذات الصلة.

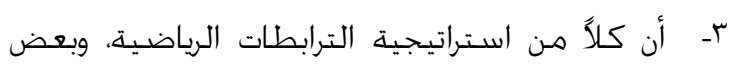

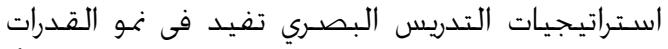

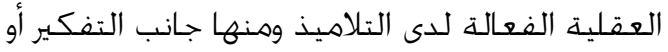

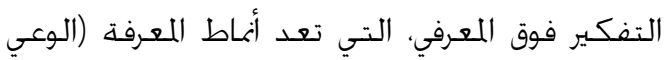

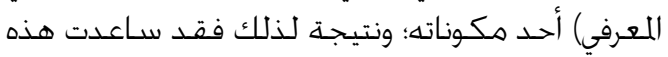

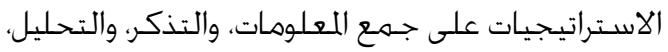
والتركيب، والتقوم للمعرفة المعروضة أمام تلاميذ لاميذ الصف الأول الإعدادي.

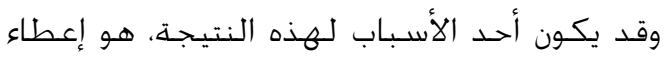

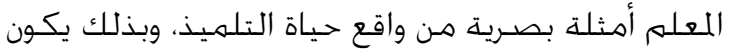

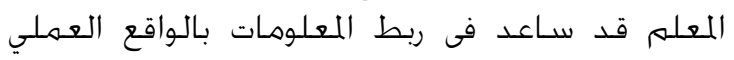

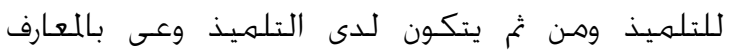
الرياضية والمتهثلة في: المعرفة المفاهيمية، والمعرفة لتائة الإجرائية، والمعرفة الشـرطية.

\section{الدلالة العلمية والعملية لنتائج هذا البحث:}

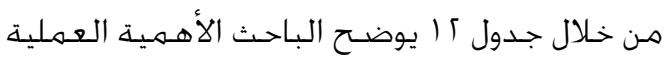

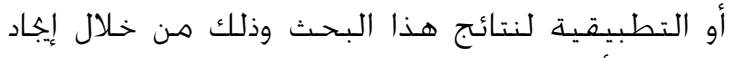

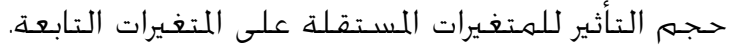

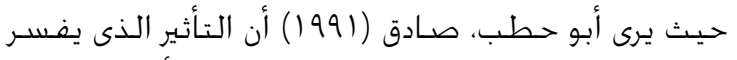

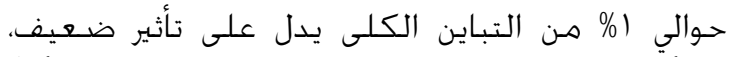

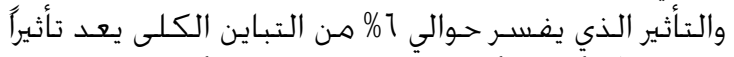

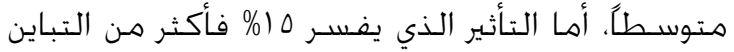

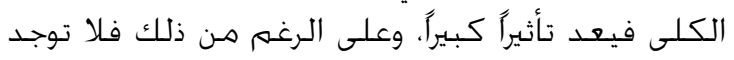

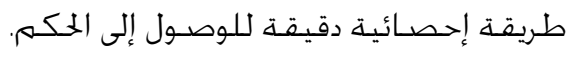

جدول

\begin{tabular}{|c|c|c|c|}
\hline \multicolumn{4}{|c|}{ الأهمية العلية والتطبيقية لننائج البحث } \\
\hline حجم التأثير & مقدار & المتغير التابع & المتغير المستقل \\
\hline \multirow{2}{*}{ كبير } & $\cdot, r)$ & مستويات تجيزيز & \\
\hline & & 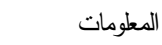 & استراتيجية \\
\hline \multirow{2}{*}{ كبير } & ., r. & تقويم أنماط المعرفة & الترابطات الرياضية \\
\hline & & الرياضية & \\
\hline \multirow{2}{*}{ كبير } & 更 & مستويات تجيزيز & نضض \\
\hline & & 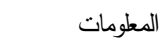 & \\
\hline \multirow{2}{*}{ كبير } & r & تقويم أنماط المعرفة & (1) \\
\hline & & الرياضية & \\
\hline
\end{tabular}

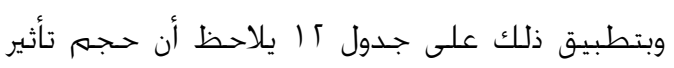

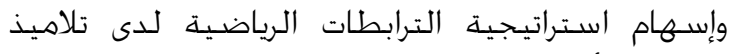

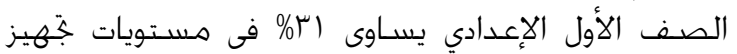


جامعة الإمارات العربية المتحدة. السـنة عا، العددا (ا.

IIV - IN0

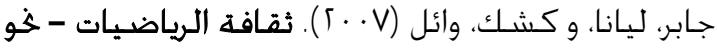

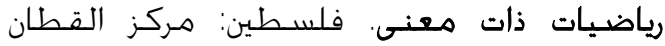
للبحتث والتطوير التربوي.

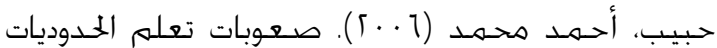

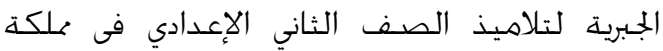
البحرين وهقترحات لعلاجها. مجلة العلوم التربوية

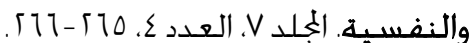

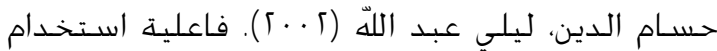

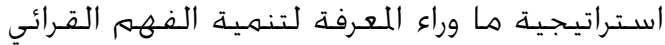

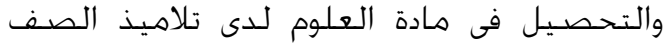
الثاني الإعدادي. مجلة التربية العلمية. كلية التربية

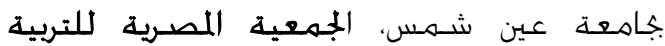

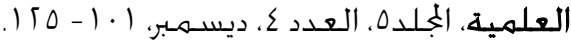
خصاونه، أمل (99VV). أثر البنية اللغوية للمسيائل اللفظية

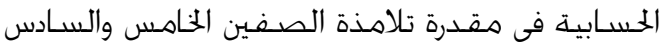

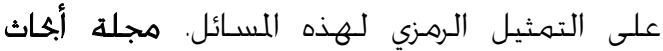

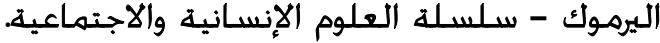
الجملد با (ا، العدد (ب)، 99 -0 1)

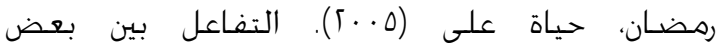

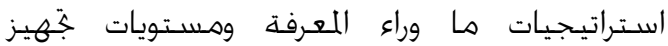

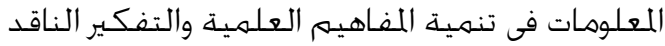

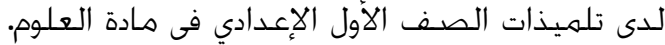

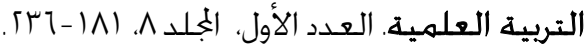

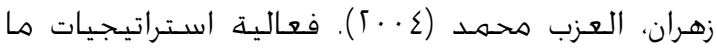

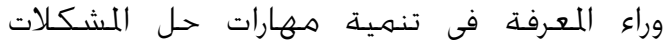

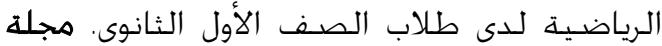

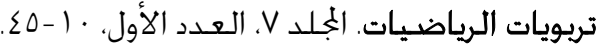
طلبة، إيهاب جودة (9 . + ؟). أثر التفاعل بين استراتيجية

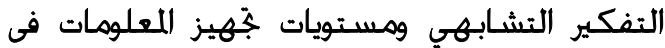

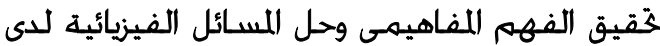

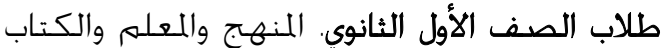

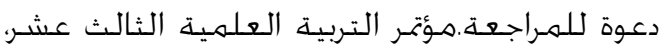
$.1 \wedge 9-1 \cdot 9 . \Sigma-5$

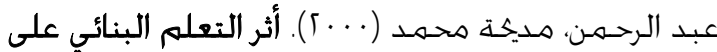

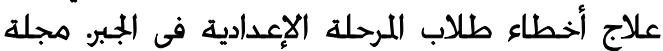

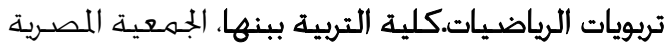

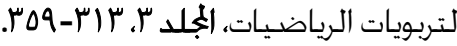

عبيد، وليم (ع . ؟). المعرفة وما وراء المعرفة - المفهوم

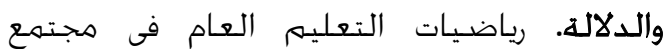

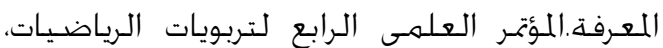

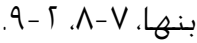

r- أثر التفاعل بين استراتيجية الترابطات الرياضية،

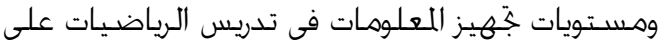

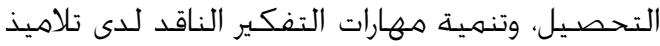
الصف الأول الإعدادي. r- أثر التفاعل بين بعض الإعتراتيجيات التدريس البصـري

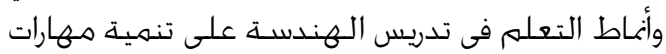

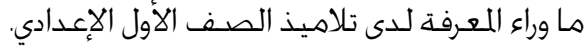

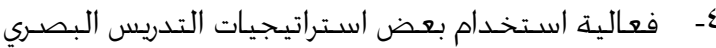

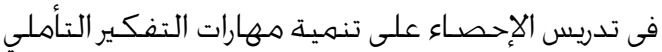
لدى تلاميذ الصـف الأول الإعدادي.

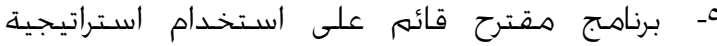

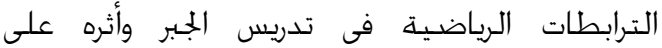

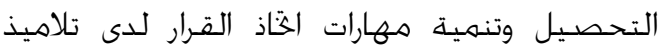
المرحلة الإعدادية.

المر اجع

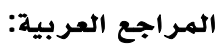

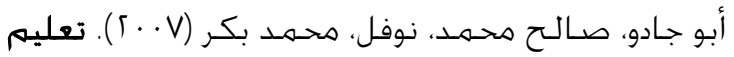
التفكير - النظرية والتطبيق، عمان: دار المسـيرة. أبو حطب، فؤاد ، صسادق، آمال (1991). مناهج البحث وطرق

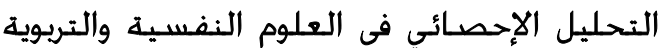
والاجتمـاعية. القاهرة مكتبة الأجنلو المصرية. الحارثي، إبراهيم (999 ()). تعليم التفكير. الرياض: هدارس

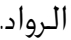

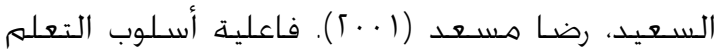

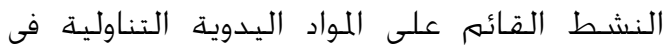

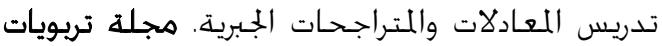

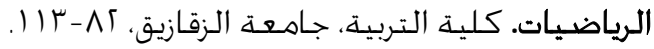

السـيد، وليد شـوقى (9 ( ؟). طرق المعرفة الإجرائية

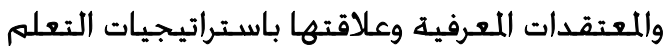

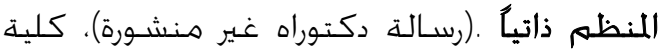
التربية، جاهعة الزقازيق.

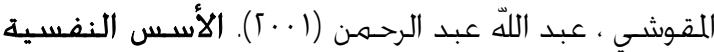

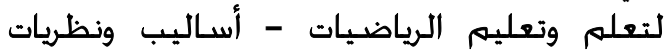
معاصـرة. الرياض: مكتبة الملك فهد الوطنية.

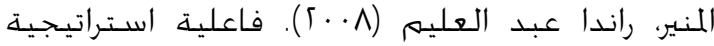

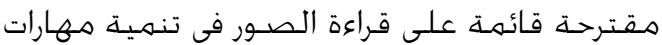

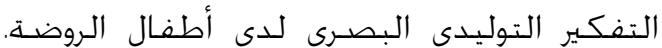

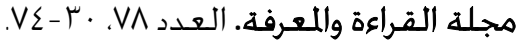

الوهر، محمود طاهر، أبو عليا، محمد مصطفى (999 ()).

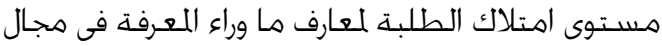

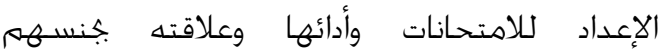
وختصيلهم ومستوى دراستهم: مجلة كلية التربية 


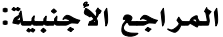

Cox, K. \& Clark, D. (1998). The use of formative quizzes for deep learning. Journal of Computers and Education, 30 (3/ 4), 157-167.

Gordon, J. (1996). Tracks for learning :metacognition and learning technologies. A ustralian Journal of Educational Technology, 12 (1), 46-55.

Gordon, J. (1996). Tracks for learning: metacognition and learning technologies. A ustralian Journal of Educational Technology, 12 (1), 46-55.

Kandarakis, G. \& Poulos, S. (2008). Teaching implications of information processing theory and evaluation approach of learning strategies using LVQ neural network. Journal of Wseas Transactions on Advances in Engineering Education, 3 (5), 111-119.

Rudolph, J. \& Popp, E. (2007). An Information processing theory of ambivalence. Journal Political Psychology, 28 (5), 563-585.

Wang, Y. (2009). The cognitive informatics theory and mathematical models of visual information processing in the brain. International Journal of Cognitive Informatics and $\mathrm{N}$ atural Intelligence, 3(3), 1-11.

Zan, R. (2000). A metacognitive intervention in mathematics at university level. International Journal of $M$ athematics in Science and Technology, 31(1), 220-235.

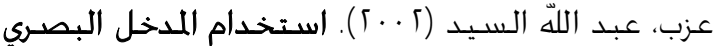

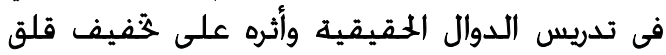
الرياضيات والتحصيل لدى طلاب التعليم الثانوي

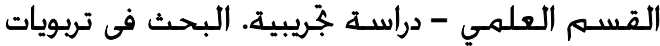

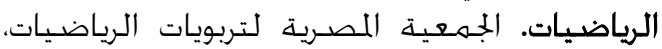

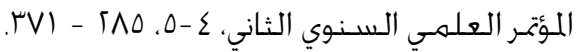

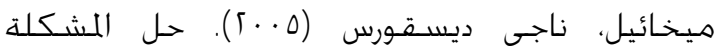

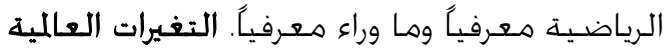

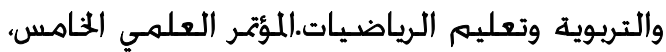

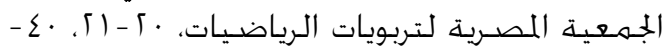

